\title{
Assessing the temporal scale of deep-sea mining impacts on sediment biogeochemistry
}

\author{
Laura Haffert $^{1}$, Matthias Haeckel ${ }^{1}$, Henko de Stigter ${ }^{2}$, and Felix Janssen ${ }^{3,4}$ \\ ${ }^{1}$ GEOMAR Helmholtz Centre for Ocean Research Kiel, Wischhofstrasse 1-3, 24148 Kiel, Germany \\ ${ }^{2}$ NIOZ - Royal Netherlands Institute for Sea Research, Department of Ocean Systems, and Utrecht University, P.O. Box 59, \\ 1790 AB Den Burg, Texel, the Netherlands \\ ${ }^{3}$ HGF MPG Joint Research Group for Deep-Sea Ecology and Technology, Alfred Wegener Institute Helmholtz Centre for \\ Polar and Marine Research, Am Handelshafen 12, 27570 Bremerhaven, Germany \\ ${ }^{4}$ Max Planck Institute for Marine Microbiology, Celsiusstrasse 1, 28359 Bremen, Germany
}

Correspondence: Laura Haffert (lhaffert@geomar.de)

Received: 6 September 2019 - Discussion started: 16 September 2019

Revised: 20 February 2020 - Accepted: 27 February 2020 - Published: 26 May 2020

\begin{abstract}
Deep-sea mining for polymetallic nodules is expected to have severe environmental impacts because not only nodules but also benthic fauna and the upper reactive sediment layer are removed through the mining operation and blanketed by resettling material from the suspended sediment plume. This study aims to provide a holistic assessment of the biogeochemical recovery after a disturbance event by applying prognostic simulations based on an updated diagenetic background model and validated against novel data on microbiological processes. It was found that the recovery strongly depends on the impact type; complete removal of the reactive surface sediment reduces benthic release of nutrients over centuries, while geochemical processes after resuspension and mixing of the surface sediment are near the pre-impact state 1 year after the disturbance. Furthermore, the geochemical impact in the DISturbance and reCOLonization (DISCOL) experiment area would be mitigated to some degree by a clay-bound Fe(II)-reaction layer, impeding the downward diffusion of oxygen, thus stabilizing the redox zonation of the sediment during transient post-impact recovery. The interdisciplinary (geochemical, numerical and biological) approach highlights the closely linked nature of benthic ecosystem functions, e.g. through bioturbation, microbial biomass and nutrient fluxes, which is also of great importance for the system recovery. It is, however, important to note that the nodule ecosystem may never recover to the pre-impact state without the essential hard substrate and will
\end{abstract}

instead be dominated by different faunal communities, functions and services.

\section{Introduction}

This work is part of the Joint Programming Initiative Healthy and Productive Seas and Oceans (JPI Oceans) MiningImpact project, which is an integrated research project assessing the potential ecological impact caused by deep-sea mining for polymetallic nodules. Most of these nodules occur in the deep ocean basins at water depths greater than $4000 \mathrm{~m}$, which represents a part of the ocean that is largely unstudied. In fact, until recently it was assumed that life would be sparse in the deep ocean, where, in the absence of light, the only energy source is falling organic matter produced in the photic zone. Increased research interest and technological advances to overcome the large distances and pressure differences of over 400 times the atmospheric pressure have revealed that the deep sea hosts a surprising diversity of life forms. Information on benthic ecosystem functions, including spatial heterogeneity, temporal variability and biogeochemical feedbacks, are still limited but are an important prerequisite in the evaluation of the environmental impacts of deep-sea mining.

This work focuses on a unique study area in the Peru Basin (Fig. 1), where in 1989 a circular area with a diameter of about $2 \mathrm{nmi}$ (nautical miles) was intensely disturbed with a plough-harrow as part of the DISturbance and reCOLoniza- 


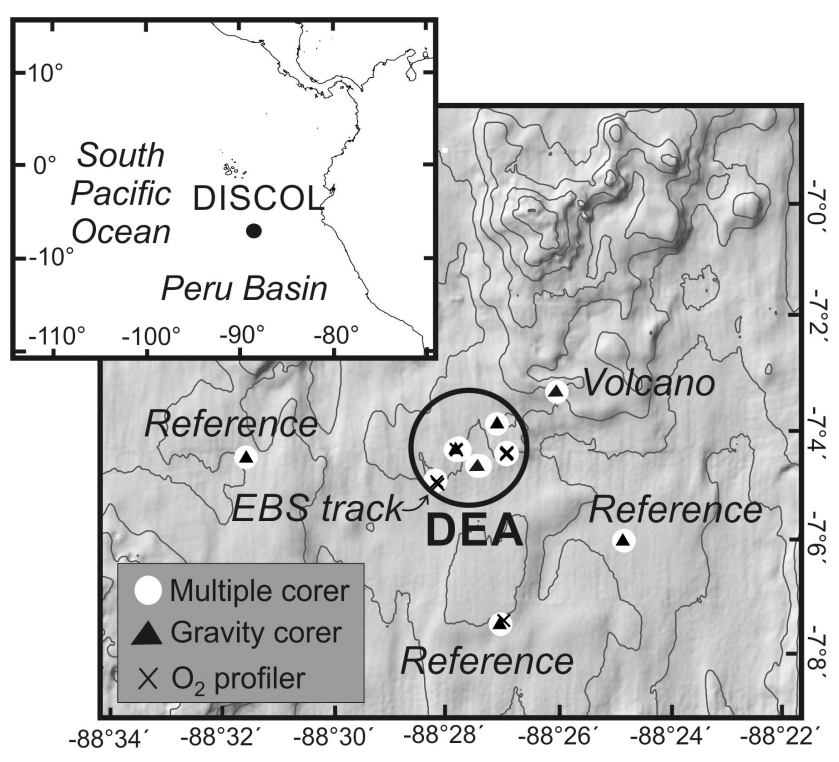

Figure 1. Bathymetric map of the DEA region in the Peru Basin including the sampling stations presented in this work. More details on the sampling locations are provided in Table 1.

tion (DISCOL) experiment (Thiel and Schriever, 1990). The DISCOL experimental area (DEA) was revisited before and several times after the initial disturbance, with research concentrating mainly on the characterization and distribution of benthic fauna (Borowski and Thiel, 1998; Borowski, 2001; Bluhm, 2001). Macrofaunal communities, which are particularly important for the bioturbation and thus redox zoning of the sediment, are mainly composed of Polychaeta (about $50 \%)$ and to a lesser extent Tanaidacea $(10 \%-20 \%)$ and $\mathrm{Bi}-$ valvia (5\%-10\%; Borowski and Thiel, 1998). After the artificial disturbance, very few faunal groups returned to baseline or control conditions after more than 2 decades (Jones et al., 2017), and the main mode of macrofaunal recolonization was found to be via lateral migration (Borowski and Thiel, 1998).

The current MiningImpact project makes use of the technological advances that have taken place in recent years, e.g. precise underwater positioning and in situ experimentation by remotely operated vehicles (ROVs), in situ oxygen measurement, precise sampling with TV-guided or ROVmanipulated equipment and analysis of microbial functions, and attempts to derive a holistic understanding of the deepsea mining impact on the closely linked ecosystem functions. The specific objectives of this work are as follows:

i. creating a biogeochemical (diagenetic) reference model for the DEA region and validating it based on a comprehensive set of geochemical data (pore water and solid phases from undisturbed and disturbed sediments) obtained with state-of-the-art methodology

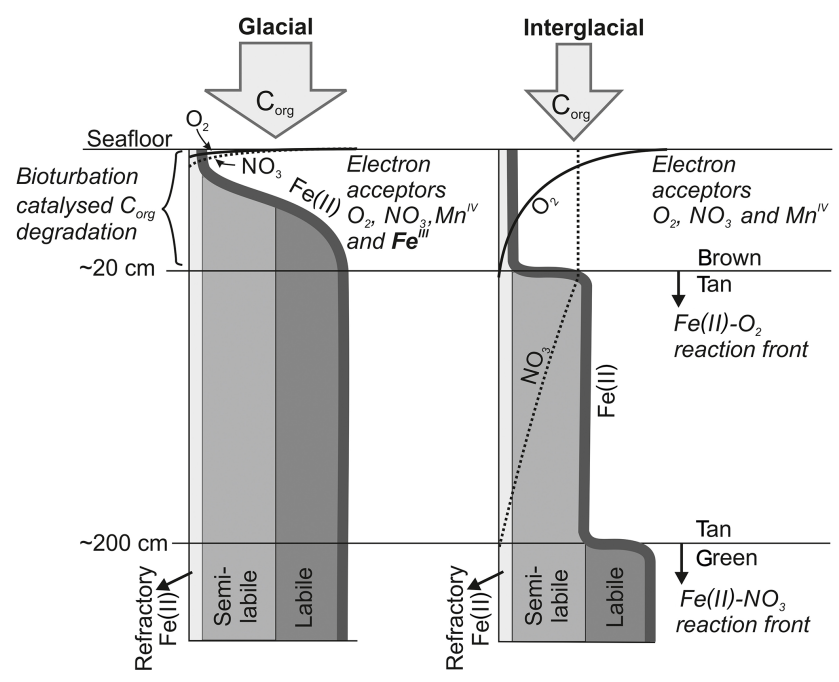

Figure 2. Schematic diagram (not to scale) outlining the formation of a Fe(II)-rich clay phase (green) in the context of glacially high organic-matter input and its conversion to Fe(III) by downward progressing $\mathrm{NO}_{3}$ fronts during interglacial periods triggered by reduced organic-matter input as postulated by König et al. (2001). In this study, we propose that a second reaction front exists impeding the downward $\mathrm{O}_{2}$ migration through a reaction with the semi-labile $\mathrm{Fe}(\mathrm{II})$ phase.

ii. determining short- to long-term impacts of a deep-sea mining event on the geochemical system through fielddata-supported simulations

iii. advancing our understanding of the intricate interplay between ecosystem functions and geochemical processes in the context of a benthic disturbance in the deep sea.

\section{Methods}

\subsection{Biogeochemical site description}

In comparison to other abyssal areas, the Peru Basin receives high organic-matter input, which is fuelled by the equatorial high-productivity zone (Weber et al., 2000). The degradation of deposited organic matter plays a crucial role in defining the benthic biogeochemical system (Froelich et al., 1979). The reactions utilize different terminal electron acceptors of the order of decreasing free-energy production, namely oxygen, nitrate, manganese oxide, iron oxide and sulfate, and their availability controls the position of the various redox zones in the sediment column. König et al. $(1999,2001)$ and Haeckel et al. (2001) have previously identified and quantified, through diagenetic modelling, the main biogeochemical processes in the Peru Basin, including the DEA region. They found that organic-matter degradation progresses through the stages of oxic respiration, denitrification, manganese and in 
deeper sediments iron oxide reduction before the reactive fraction of organic matter are diminished, leaving only the most refractory fraction of organic material to be permanently buried. Unlike manganese, the reduced Fe(II) species is not released into the pore water but instead incorporated into the clay mineral phase as nontronite, resulting in dissolved Fe concentrations below or near the detection limit. The largest quantity of organic matter is degraded by oxic respiration in a surface "reaction layer" which coincides with the bioturbated zone. Oxygen is depleted in the Peru Basin at a sediment depth of 5 to $15 \mathrm{~cm}$, the latter being the typical oxygen penetration depth within the DEA region (Haeckel et al., 2001). Larger variations were found among the nitrate profiles. In the slightly shallower region of the Peru Basin, seawater-derived nitrate and nitrate from oxic respiration are consumed within the bioturbated upper $20 \mathrm{~cm}$ of sediment. In contrast, in the DEA region nitrate escapes the reaction layer and diffuses to a depth of about $2 \mathrm{~m}$, where a Fe(II)rich layer impedes further downward migration (König et al., 2001; see also Fig. 2). This Fe(II)-rich layer was formed during glacial times (corresponding to an age of at least $60 \mathrm{ka}$ ), when organic-matter deposition was strongly increased and potential electron acceptors such as oxygen, nitrate and manganese oxide were exhausted closely below the sediment surface (König et al., 2001). During these times, structural $\mathrm{Fe}(\mathrm{III})$ within smectite lattices acted as the thermodynamically favoured electron acceptor, creating Fe(II)-rich surface sediments that were subsequently buried (Lyle, 1983). This process was reversed when waning organic-matter input during interglacial periods allowed oxygen and nitrate to migrate downwards, thus creating a "burn-down" situation of the redox-sensitive Fe(II)-rich smectite phase (Fig. 2). The position of the reaction front is easily distinguished in deep sediment cores as a transition from a tan to green colour change (Lyle, 1983) and has also been confirmed by Mössbauer spectroscopic measurements (Drodt et al., 1997; König et al., 1997, 1999).

Comparatively little is known about the redox potential of $\mathrm{Fe}(\mathrm{II})$ on different crystallographic lattice positions (coordination sites) in clay minerals such as nontronite. In particular, information is lacking on the reactivity of the Fe(II) on these sites with respect to oxidation by nitrate and oxygen. Available Mössbauer data (König et al., 2001) from the DISCOL area indicate a refractory fraction of $\mathrm{Fe}(\mathrm{II})$ that prevails in the nitrate reduction zone ( $\sim 10 \%$ of total iron). We propose that part of this refractory fraction is in fact semi-labile and that oxygen, which has a higher redox potential than nitrate, can oxidize this semi-labile Fe(II) and thus presents a second reaction front impeding the downward migration of oxygen.

\subsection{Disturbance experiments}

The current study presents information collected in the DEA during the two legs of the SO242 research cruise in 2015. The DISCOL experiment was designed to artificially disturb the surface sediment layer through mixing and remove nodules from the surface with a specially designed device, the so-called plough-harrow (Thiel and Schriever, 1990). To this end the $\sim 4150 \mathrm{~m}$ deep circular DEA $\left(11 \mathrm{~km}^{2}\right)$ was crossed 78 times starting from various directions, resulting in a heavily disturbed area in the centre and less disturbed peripheral regions. In total about $20 \%$ of the DEA was directly ploughed, with the remaining $80 \%$ being not directly disturbed but - at least in part - covered by an up to $30 \mathrm{~mm}$ thick resettled sediment blanket (Schriever and Thiel, 1992).

During the first leg of SO242 an additional artificial disturbance was created using an epibenthic sled (EBS) which was sampled 5 weeks later on the second leg of SO242. The epibenthic sled (CliSAP-Sled; Brenke, 2005) has a width of $2.4 \mathrm{~m}$ and weight of $880 \mathrm{~kg}$ (in air). Unlike the ploughharrow, which "mixes" the upper sediment layer, the EBS largely scrapes off the upper centimetres of sediment (most of the reactive, bioturbated layer), including embedded nodules, and bulldozes them sideways from the track.

\subsection{Sampling procedure}

A map of the sampling stations and a table of the exact positions are provided in Fig. 1 and Table 1, respectively. Several devices were deployed at each sampling site to retrieve surface and subsurface sediment samples (Greinert, 2015; Boetius, 2015): (i) a multiple corer (MUC, Oktopus, Kiel, Germany), which samples the upper $20-40 \mathrm{~cm}$ of the sediment including the overlying bottom water and was equipped with a TV-camera system for precise positioning, e.g. for sampling specific seafloor features like the disturbance tracks, (ii) a ROV-deployed push corer (PUC) focusing on small-scale topographic features created by the seafloor disturbance, (iii) a box corer (BC - USNEL type; Hessler and Jumars, 1974) to sample the sediment including macrofauna and nodules, and (iv) a gravity corer (GC) extracting sediment up to $10 \mathrm{~m}$ b.s.f.

After core retrieval the samples were brought into the ship's cold room (approx. $4^{\circ} \mathrm{C}$ ); $1 \mathrm{~m}$ long sections of the gravity cores were cut into two half-cylinders dedicated for sampling and archiving. The working half of the gravity cores were sampled by extracting $3 \mathrm{~cm}$ thick slices at intervals of 20 to $40 \mathrm{~cm}$. Sediment from the plastic liners of the other corers were extruded with a piston and cut into 0.5 to $2 \mathrm{~cm}$ thick slices under an oxygen-free, argon atmosphere in a glove bag. Subsequently, the pore water was extracted using a low-pressure squeezer (argon gas at 3-5 bar) and filtered through a Nuclepore $0.2 \mu \mathrm{m}$ polycarbonate filter. Pore water extracted from the samples was stored in two recipient vessels: (i) an acidified sample (i.e. $\mathrm{pH}<1$ with $20 \mu \mathrm{L}$ $30 \% \mathrm{HCl}$ Suprapur per $1 \mathrm{~mL}$ sample) for analysis of metal cations and (ii) a non-acidified sample for nutrients. Additional sediment samples were collected from the same core and sediment intervals for porosity, organic carbon content and radiometric analysis. 
Table 1. Sampling station locations and description.

\begin{tabular}{|c|c|c|c|c|c|}
\hline Area & Station & Description & Latitude (S) & Longitude (W) & Water depth (m) \\
\hline \multicolumn{6}{|c|}{ Reconnaissance } \\
\hline \multirow{12}{*}{ 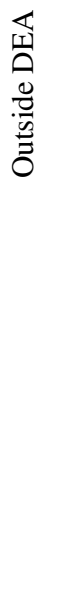 } & & Southern reference & & & \\
\hline & 38GC1 & Southern reference with nodules & $7^{\circ} 07.537^{\prime}$ & $88^{\circ} 27.047^{\prime}$ & 4161 \\
\hline & 34MUC6 & Southern reference with nodules & $7^{\circ} 07.524^{\prime}$ & $88^{\circ} 27.031^{\prime}$ & 4162 \\
\hline & & Western reference & & & \\
\hline & 89GC4 & Western reference with nodules & $7^{\circ} 04.562^{\prime}$ & $88^{\circ} 31.577^{\prime}$ & 4125 \\
\hline & 80MUC22 & Western reference with nodules & $7^{\circ} 04.542^{\prime}$ & $88^{\circ} 31.581^{\prime}$ & 4130 \\
\hline & & Eastern reference & & & \\
\hline & 123GC6 & Eastern reference with(out) nodules & $7^{\circ} 06.045^{\prime}$ & $88^{\circ} 24.848^{\prime}$ & 4208 \\
\hline & 119MUC31 & Eastern reference with(out) nodules & $7^{\circ} 06.033^{\prime}$ & $88^{\circ} 24.826^{\prime}$ & 4204 \\
\hline & & Volcano crater & & & \\
\hline & 132GC7 & Small volcano crater with dense nodules & $7^{\circ} 03.369^{\prime}$ & $88^{\circ} 26.031^{\prime}$ & 4152 \\
\hline & 129BC26 & Small volcano crater with dense nodules & $7^{\circ} 03.373^{\prime}$ & $88^{\circ} 26.026^{\prime}$ & 4144 \\
\hline \multirow{11}{*}{ 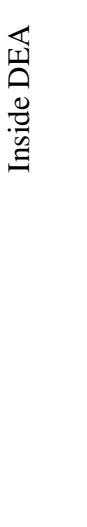 } & & DEA plough tracks & & & \\
\hline & $51 \mathrm{GC} 2$ & DEA west plough tracks & $7^{\circ} 04.411^{\prime}$ & $88^{\circ} 27.836^{\prime}$ & 4148 \\
\hline & 56MUC12 & DEA west plough tracks & $7^{\circ} 04.414^{\prime}$ & $88^{\circ} 27.760^{\prime}$ & 4149 \\
\hline & 61MUC13 & DEA west outside plough tracks & $7^{\circ} 04.378^{\prime}$ & $88^{\circ} 27.781^{\prime}$ & 4148 \\
\hline & 70MUC17 & DEA west resettled sediment plume & $7^{\circ} 04.400^{\prime}$ & $88^{\circ} 27.778^{\prime}$ & 4128 \\
\hline & & DEA black patch & & & \\
\hline & 84GC3 & DEA black patch in side-scan sonar & $7^{\circ} 03.951^{\prime}$ & $88^{\circ} 27.093^{\prime}$ & 4146 \\
\hline & 74MUC20 & DEA black patch in side-scan sonar & $7^{\circ} 03.945^{\prime}$ & $88^{\circ} 27.097^{\prime}$ & 4150 \\
\hline & & DEA central/trough & & & \\
\hline & 100GC5 & DEA central & $7^{\circ} 04.342^{\prime}$ & $88^{\circ} 27.442^{\prime}$ & 4151 \\
\hline & 108MUC26 & DEA central & $7^{\circ} 04.483^{\prime}$ & $88^{\circ} 26.919^{\prime}$ & 4169 \\
\hline \multicolumn{6}{|c|}{ Microhabitats } \\
\hline & & Reference & & & \\
\hline & 34MUC6 & Southern reference with nodules & $7^{\circ} 07.524^{\prime}$ & $88^{\circ} 27.031^{\prime}$ & 4162 \\
\hline & 80MUC22 & Western reference with nodules & $7^{\circ} 04.542^{\prime}$ & $88^{\circ} 31.581^{\prime}$ & 4130 \\
\hline & 119MUC31 & Eastern reference with or without nodules & $7^{\circ} 06.033^{\prime}$ & $88^{\circ} 24.826^{\prime}$ & 4204 \\
\hline & & DEA outside tracks & & & \\
\hline & 61MUC13 & DEA west outside plough track & $7^{\circ} 04.378^{\prime}$ & $88^{\circ} 27.781^{\prime}$ & 4148 \\
\hline & 146ROVPC79 & DEA west $20 \mathrm{~m}$ off plough track & $7^{\circ} 04.4000^{\prime}$ & $88^{\circ} 27.8266^{\prime}$ & 4140 \\
\hline & 166ROVPC70 & DEA east $20 \mathrm{~m}$ off plough track & $7^{\circ} 04.4585^{\prime}$ & $88^{\circ} 26.9240^{\prime}$ & 4143 \\
\hline & 229MUC & DEA south outside plough track & $7^{\circ} 04.6970^{\prime}$ & $88^{\circ} 27.3970^{\prime}$ & 4133 \\
\hline & & DEA track furrow & & & \\
\hline & 146ROVPC77 & DEA west plough furrow & $7^{\circ} 04.4110^{\prime}$ & $88^{\circ} 27.8363^{\prime}$ & 4139 \\
\hline & 166ROVPC69 & DEA east plough furrow & $7^{\circ} 04.4780^{\prime}$ & $88^{\circ} 26.9178^{\prime}$ & 4143 \\
\hline & 219ROVPC75 & DEA south plough furrow & $7^{\circ} 04.6930^{\prime}$ & $88^{\circ} 27.4540^{\prime}$ & 4155 \\
\hline
\end{tabular}


Table 1. Continued.

\begin{tabular}{|c|c|c|c|c|c|}
\hline Area & Station & Description & Latitude (S) & Longitude (W) & Water depth (m) \\
\hline & & \multicolumn{4}{|l|}{ DEA ridge } \\
\hline & 142ROVPC33 & DEA west plough ridge & $7^{\circ} 04.4094^{\prime}$ & $88^{\circ} 27.8330^{\prime}$ & 4139 \\
\hline & 163ROVPC83 & DEA east plough ridge & $7^{\circ} 04.4926^{\prime}$ & $88^{\circ} 26.9333^{\prime}$ & 4143 \\
\hline \multirow{2}{*}{\multicolumn{2}{|c|}{ 232ROVPC64 }} & DEA south plough ridge & $7^{\circ} 04.6890^{\prime}$ & $88^{\circ} 27.4554^{\prime}$ & 4156 \\
\hline & & \multicolumn{4}{|l|}{ DEA subsurface patch } \\
\hline & 142ROVPC48 & DEA west subsurface patch & $7^{\circ} 04.4113^{\prime}$ & $88^{\circ} 27.8127^{\prime}$ & 4140 \\
\hline & 169ROVPC83 & DEA east subsurface patch & $7^{\circ} 04.4808^{\prime}$ & $88^{\circ} 26.9130^{\prime}$ & 4144 \\
\hline & \multirow[t]{2}{*}{ 219ROVPC58 } & DEA south subsurface patch & $7^{\circ} 04.6930^{\prime}$ & $88^{\circ} 27.4540^{\prime}$ & 4155 \\
\hline & & \multicolumn{4}{|l|}{ EBS track } \\
\hline & 202ROVPC80 & DEA west inside EBS track & $7^{\circ} 04.9533^{\prime}$ & $88^{\circ} 28.1980^{\prime}$ & 4150 \\
\hline & 202ROVPC18 & DEA west side pile EBS track & $7^{\circ} 04.9609^{\prime}$ & $88^{\circ} 28.1907^{\prime}$ & 4150 \\
\hline & 211ROVPC52 & DEA west rim inside EBS track & $7^{\circ} 04.9581^{\prime}$ & $88^{\circ} 28.1909^{\prime}$ & 4150 \\
\hline & 211ROVPC73 & DEA west outside of EBS track & $7^{\circ} 04.9669^{\prime}$ & $88^{\circ} 28.1929^{\prime}$ & 4150 \\
\hline \multicolumn{6}{|c|}{ In situ oxygen profiles } \\
\hline & & \multicolumn{4}{|l|}{ Reference } \\
\hline & 158LANDER no. 1 & Reference south & $7^{\circ} 7.4590^{\prime}$ & $88^{\circ} 26.9740^{\prime}$ & 4155 \\
\hline & & \multicolumn{4}{|l|}{ Undisturbed DEA } \\
\hline & 176ROV profiler no. 1 & DEA E outside track & $7^{\circ} 4.4677^{\prime}$ & $88^{\circ} 26.9187^{\prime}$ & 4102 \\
\hline & 169ROV profiler no. 1 & DEA E outside track & $7^{\circ} 4.4563^{\prime}$ & $88^{\circ} 26.9176^{\prime}$ & 4102 \\
\hline & 213ROV profiler no. 2 & EBS outside track & $7^{\circ} 5.0220^{\prime}$ & $88^{\circ} 28.1526^{\prime}$ & 4189 \\
\hline & 146ROV profiler no. 2 & DEA W outside track & $7^{\circ} 4.4000^{\prime}$ & $88^{\circ} 27.8274^{\prime}$ & 4140 \\
\hline & & \multicolumn{4}{|l|}{ DEA plough tracks } \\
\hline & 176ROV profiler no. 2 & Subsurface & $7^{\circ} 4.4762^{\prime}$ & $88^{\circ} 26.9190^{\prime}$ & 4102 \\
\hline & 154ROV profiler no. 2 & Subsurface & $7^{\circ} 4.4118^{\prime}$ & $88^{\circ} 27.8172^{\prime}$ & 4101 \\
\hline & 166ROV profiler no. 2 & Furrow & $7^{\circ} 4.4898^{\prime}$ & $88^{\circ} 26.9286^{\prime}$ & 4104 \\
\hline & \multirow[t]{2}{*}{ 169ROV profiler no. 2} & Furrow & $7^{\circ} 4.4787^{\prime}$ & $88^{\circ} 26.9205^{\prime}$ & 4104 \\
\hline & & \multicolumn{4}{|l|}{ EBS track } \\
\hline & 202ROV profiler no. 1 & Inside track & $7^{\circ} 4.9787^{\prime}$ & $88^{\circ} 28.1730^{\prime}$ & 4189 \\
\hline
\end{tabular}

\subsection{Analytical methods}

Analyses for the pore water solutes $\mathrm{NO}_{3}^{-}, \mathrm{NO}_{2}^{-}, \mathrm{NH}_{4}^{+}, \mathrm{PO}_{4}^{3-}$ and $\mathrm{SiO}_{4}^{4-}$ were completed onboard using a Hitachi UV/VIS spectrophotometer on $1.3 \mathrm{~mL}$ of freshly extracted untreated pore water which was diluted 3 fold before analysis. The respective chemical analytics followed standard procedures (Grasshoff et al., 1999); i.e. nitrite and nitrate (after reduction with $\mathrm{Cd}$ ) were measured as sulfanile-naphthylamide, ammonium was measured as indophenol blue, phosphate and silicate as molybdenum blue, and iron with ferrospectral. The total alkalinity of the pore water was determined by titration with $0.02 \mathrm{~N} \mathrm{HCl}$ using a mixture of methyl red and methylene blue as an indicator. The titration vessel was bubbled with argon to strip any $\mathrm{CO}_{2}$ produced during the titration. The IAPSO seawater standard was used for calibration. Fur- ther details on analytical methods, e.g. analytical precision and accuracy, are given in Table 2 .

At the NIOZ laboratory sediment profiles of ${ }^{210} \mathrm{~Pb}$ and ${ }^{226} \mathrm{Ra}$, radioisotopes from the ${ }^{234} \mathrm{U}$ decay series were measured in multicores for determining biological mixing rates integrated over a $\sim 100$-year timescale. Total ${ }^{210} \mathrm{~Pb}$ and ${ }^{226} \mathrm{Ra}$ activity was determined directly by gamma spectrometry, whilst total ${ }^{210} \mathrm{~Pb}$ was also measured indirectly by alpha spectrometry via its granddaughter isotope ${ }^{210} \mathrm{Po}$. Activities of anthropogenic ${ }^{137} \mathrm{Cs}$ proved to be generally below the detection level. Radionuclide activities are reported in the database as millibecquerels per gram of dry sediment.

For gamma spectrometry, a few grams of a freeze-dried and homogenized sediment sample was contained in a $5 \mathrm{~cm}$ diameter plastic petri dish, which was closed with tape and sealed gas-tight in a plastic envelope. After leaving the sample for at least 4 weeks to ensure equilibrium, measure- 
Table 2. Summary of analysed properties, analytical methods, estimated analytical errors and detection limits.

\begin{tabular}{|c|c|c|}
\hline Parameter & Method & Error (detection limit) ${ }^{\mathrm{a}}$ \\
\hline $\mathrm{NO}_{3}^{-}$ & Spectrophotometer (as sulfanile- $\alpha$-naphthylamide) ${ }^{\mathrm{b}}$ & $1 \mu \mathrm{mol} \mathrm{L}{ }^{-1}$ \\
\hline $\mathrm{NO}_{2}^{-}$ & Spectrophotometer (as sulfanile- $\alpha$-naphthylamide) ${ }^{b}$ & $1 \mu \mathrm{mol} \mathrm{L}{ }^{-1}$ \\
\hline $\mathrm{NH}_{4}^{+}$ & Spectrophotometer (as indophenol blue) ${ }^{\mathrm{b}}$ & $1 \mu \mathrm{mol} \mathrm{L}^{-1}$ \\
\hline $\mathrm{Mn}^{2+}$ & ICP-AES & $5 \%-10 \%(1 \mu \mathrm{mol} \mathrm{L}-1)$ \\
\hline $\mathrm{SO}_{4}^{2-}$ & Ion chromatography & $0.8-1.2 \mathrm{mmol} \mathrm{L}^{-1}\left(5 \mathrm{mmol} \mathrm{L}^{-1}\right)$ \\
\hline$C_{\text {org }}$ & $\mathrm{CHN}$ analyser ${ }^{\mathrm{c}}$ & $0.04 \mathrm{wt} \%$ \\
\hline Alkalinity & Titration $^{\mathrm{d}}$ & $0.05 \mathrm{meq}^{-1}$ \\
\hline Porosity & Weight difference before and after drying of the sediment & 0.02 \\
\hline
\end{tabular}

${ }^{a}$ For some properties no analytical error could be determined because of few data points or concentrations close to the detection limit.

${ }^{b}$ Grasshoff et al. (1999). ${ }^{c}$ Welicky et al. (1983). ${ }^{d}$ Breland and Byrne (1993).

ment of ${ }^{210} \mathrm{~Pb}$ and ${ }^{226} \mathrm{Ra}$ was undertaken with a Canberra Broad Energy Range High Purity Germanium (BEGe) detector, using the $46.5 \mathrm{keV}$ line for ${ }^{210} \mathrm{~Pb}$ and 295.2, 351.9 and $609.3 \mathrm{keV}$ lines for ${ }^{226} \mathrm{Ra}$. The detector, connected to a computer via a digital spectrum analyser (DSA-1000), counted the radionuclide activities with Genie 2000 gamma spectroscopy software. The detector was externally calibrated with a Geological Certified Reference Material IAEA/RGU1 , with a reference date of 1 January 1988. A monitor standard IAEA-300 provided quality control. Excess ${ }^{210} \mathrm{~Pb}$ activities were calculated by subtracting ${ }^{226} \mathrm{Ra}$ activity averaged for the 295.2, 351.9 and $609.3 \mathrm{keV}$ lines from the measured total ${ }^{210} \mathrm{~Pb}$ activity.

For alpha spectrometry measurement of ${ }^{210} \mathrm{Po}, 0.5 \mathrm{~g}$ of a freeze-dried and homogenized sediment sample was spiked with $1 \mathrm{~mL}$ of a standard solution of ${ }^{209} \mathrm{Po}$ in $2 \mathrm{M} \mathrm{HCl}$ and then leached for $6 \mathrm{~h}$ in $10 \mathrm{~mL}$ of concentrated $\mathrm{HCl}$ heated to $85^{\circ} \mathrm{C}$. After diluting the fluid with $45 \mathrm{~mL}$ of demineralized water and adding $5 \mathrm{~mL}$ of an aqueous solution of ascorbic acid $\left(40 \mathrm{~g} \mathrm{~L}^{-1}\right)$, natural ${ }^{210} \mathrm{Po}$ and added ${ }^{209}$ Po were collected from the fluid by spontaneous electrochemical deposition on silver plates. For subsequent alpha spectrometry, Canberra Passivated Implanted Planar Silicon detectors were used. ${ }^{210} \mathrm{~Pb}$ activity was calculated from ${ }^{210} \mathrm{Po}$, assuming secular equilibrium and correcting for the time elapsed since collection of the samples.

\subsection{Numerical methods}

We follow the classical approach in early diagenetic modelling, where partial differential equations represent the diffusive and advective fluxes coupled to a reaction term $(R)$, as formulated by Berner (1980). When applying a conversion via the volume fraction, the following expressions for solutes and solids can be derived, respectively:

$$
\frac{\partial \phi C_{\mathrm{pw}}}{\partial t}=\frac{\partial}{\partial x}\left(\phi D \frac{\partial C_{\mathrm{pw}}}{\partial x}-\phi u C_{\mathrm{pw}}\right)-\phi R\left(C_{\mathrm{pw}}\right)
$$

and

$$
\begin{aligned}
& \frac{\partial(1-\phi) C_{\mathrm{s}}}{\partial t}=\frac{\partial}{\partial x}\left((1-\phi) D_{\mathrm{b}} \frac{\partial C_{\mathrm{s}}}{\partial x}-(1-\phi) w C_{\mathrm{s}}\right) \\
& -(1-\phi) R\left(C_{\mathrm{s}}\right),
\end{aligned}
$$

where $t$ and $x$ represent time and the depth under the seafloor, respectively, $C_{\mathrm{pw}}$ and $C_{\mathrm{s}}$ are the molar species concentration of solute or solid, respectively, $\phi$ is the porosity, and $u$ and $w$ represent fluid and sediment velocity due to burial. Solute diffusion and sediment bioturbation are scaled by the effective diffusion coefficient $D$ and the bioturbation coefficient $D_{\mathrm{b}}$.

The porosity-depth profile is assumed to be produced by steady-state compaction (Berner, 1980) and is approximated empirically by the following exponential function (Murray et al., 1978; Berner, 1980; Martin et al., 1991; Rabouille and Gaillard, 1991a, b):

$\phi(x)=\phi_{\infty}+\left(\phi_{0}-\phi_{\infty}\right) e^{-\beta x}$,

where $\phi_{\infty}$ is the porosity at infinite depth, $\phi_{0}$ is the porosity at the sediment surface $(x=0)$ and $\beta$ is the porosity attenuation coefficient.

The fluid and sediment velocity-depth distribution is calculated according to the mathematical convention of Luff and Wallmann (2003):

$u(x)=\frac{\phi_{\infty} w_{\infty}}{\phi(x)}$

and

$w(x)=\frac{1-\phi_{\infty}}{1-\phi(x)} w_{\infty}$,

where $w_{\infty}$ is the burial velocity at infinite depth.

The effective diffusion coefficient was tortuosity corrected:

$D(x)=\frac{D^{0}(x)}{\theta^{2}(x)}$, 
with $D_{0}$ being the infinite-dilution molecular diffusion coefficient calculated after Berner (1980) and $\theta^{2}$ being the squared tortuosity. The tortuosity can be related to the porosity $\phi$ according to Boudreau (1996):

$\theta^{2}(x)=1-2 \ln \phi(x)$.

The bioturbation profile is approximated by the arbitrary function:

$D_{\mathrm{b}}=D_{\mathrm{b}}^{0} \cdot 0.5 \operatorname{erfc}\left(\frac{x-x_{D_{\mathrm{b}}}}{\beta_{D_{\mathrm{b}}}}\right)$,

where $D_{\mathrm{b}}^{0}$ represents the maximum bioturbation intensity at the sediment surface, $x_{D_{\mathrm{b}}}$ is the bioturbation half-depth and $\beta_{D_{\mathrm{b}}}$ is the bioturbation attenuation coefficient.

The diagenetic equations, consisting of a set of partial differential equations (Eqs. 1 and 2), are solved via a finitedifference scheme (1-D uneven grid with a sigmoidal distribution ranging from $0.1 \mathrm{~cm}$ at the surface to $1 \mathrm{~cm}$ at the lower boundary) and subsequent minimization of the ordinary differential equations by inbuilt ODE (ordinary differential equation) solvers of MATLAB.

The reaction network shaping the geochemistry of the upper sediment metres, namely organic-matter degradation and secondary redox reactions including the oxidation of ammonium and dissolved manganese, is listed in Table 3 as well as the corresponding rate expressions. To account for different reactivities of the various organic-matter phases, we apply a 3G model (Jorgensen, 1978; Westrich and Berner, 1984; Middelburg, 1989) allowing for a labile, moderately reactive and refractory phase. We also included a shallow semi-labile Fe(II) layer that reacts with oxygen to the model (Fig. 2). While it is established that a labile $\mathrm{Fe}(\mathrm{II})$ reaction front impedes the downward migration of nitrate (König et al., 1997, 1999), little is known about the redox potential of $\mathrm{Fe}(\mathrm{II})$ on different crystallographic lattice positions (coordination sites) in clay minerals such as nontronite. In particular, information is lacking on the reactivity of the Fe(II) on these sites with respect to oxidation by nitrate and oxygen. Available Mössbauer data (König et al., 2001) from the DISCOL area indicate a refractory fraction of $\mathrm{Fe}(\mathrm{II})$ that prevails in the nitrate reduction zone ( $\sim 10 \%$ of total iron). In the light of the much higher redox potential of oxygen compared to nitrate, we model the remaining $\mathrm{Fe}(\mathrm{II})$ as a semilabile phase representing a second reaction front impeding the downward migration of oxygen. The diagenetic model is applied to define a background or reference geochemical system. This is then used to derive transient prognostic models in response to different impact types. Initial profiles of the transient simulations are based on the steady-state background model which was adjusted for the modelled impact type: (i) in the case of "sediment removal", the top $10 \mathrm{~cm}$ of the background profiles was "cut off" while maintaining bottom water concentrations and organic-matter flux for the upper boundary conditions. For the "sediment mixing" case, the oxygen concentrations of the upper $10 \mathrm{~cm}$ of the sediment were set to bottom water values, imitating an oxygen flooding event. Transient models were augmented by an additional $\mathrm{Fe}(\mathrm{II})$ profile - an oxygen reaction layer (Fig. 2) - as justified by the surprisingly constant oxygen penetration depth at the reference and all disturbed sites. This Fe(II) reaction layer is crucial in the prognostic simulations which would otherwise predict that oxygen rapidly diffuses into deeper sediments after a disturbance event. It is assumed that bioturbation is inhibited immediately after the impact, with a linear increase to undisturbed reference bioturbation intensity within 100 to 200 years, which is in line with macrofaunal abundance data presented in Stratmann et al. (2018a). A detailed parameterization of the background and prognostic models is provided in Table 4.

The bioturbation coefficient $D_{\mathrm{b}}^{0}$, a critical input parameter to the background model, is derived by fitting a simplified version of the background model to summed ${ }^{210} \mathrm{~Pb},{ }^{226} \mathrm{Ra}$ and ${ }^{230} \mathrm{Th}$ radiometric data. The physical set-up of the model is the same as the background model, with the difference that only the above-mentioned radiometric species and their firstorder radioactive decay is considered.

\section{Results}

\subsection{Geochemistry of the DEA region}

The parameter depth profiles for each core are presented in Figs. 3-6, grouped into "outside DEA" and "inside DEA" stations for the gravity cores and for the multiple and box cores in reference sites and various types of disturbed sites.

Geochemical trends observed in the sediment cores from reference stations agree in general well with those observed in the same area during a previous investigation (Haeckel et al., 2001). The upper reactive sediment section (up to $\sim$ $20 \mathrm{~cm}$ b.s.f) is markedly different from the deeper sediment sections (up to $10 \mathrm{~m}$; Fig. 3). It is characterized by a significant decrease in porosity (from 0.94 to approx. 0.86 ; Table 4 and Fig. 4) and is rich in manganese oxides (1-2 wt \%; Paul et al., 2019), which gives this layer its distinct dark brown colour. Below this layer, the sediment takes on a light brown to grey brown (tan) colour, which is replaced by a greyishgreen colour - the shift to $\mathrm{Fe}$ (II)-rich lattices in the smectite phase - at a depth of 2-2.5 m (38 GC 1, 84 GC 3, 100 GC 5 and 123 GC 6; Table 1). Organic carbon content in the DEA region oscillates about a mean value of 0.5 to $0.75 \mathrm{wt} \%$ in the upper $50 \mathrm{~cm}$ (Fig. 3), which is controlled by the difference in organic carbon input during glacial (higher $C_{\text {org }}$ content) and interglacial (lower $C_{\text {org }}$ content) sedimentation regimes (Haeckel et al., 2001). With depth the organic carbon content decreases steadily to about $0.1 \mathrm{wt} \%$ at 10 m.b.s.f (Fig. 3). Contrary to previous observations that nodules in the DEA area occur only at the sediment surface, investigation of the current set of gravity cores revealed buried manganese nod- 

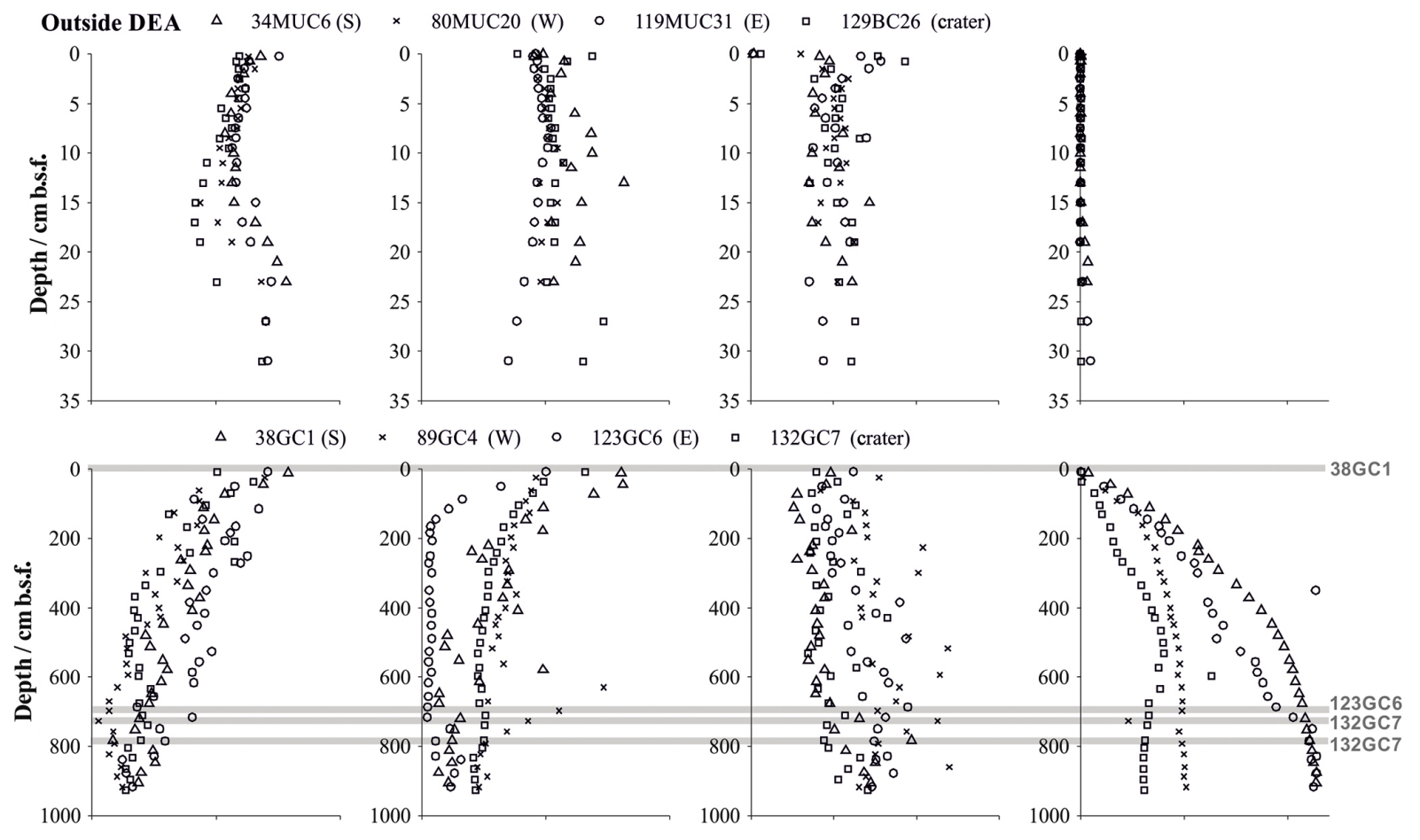

Inside DEA $\triangle 56 \mathrm{MUC12} \times 61 \mathrm{MUC13} \quad \circ 70 \mathrm{MUC17} \quad \square \quad 74 \mathrm{MUC} 20 \quad * \quad 108 \mathrm{MUC} 26$
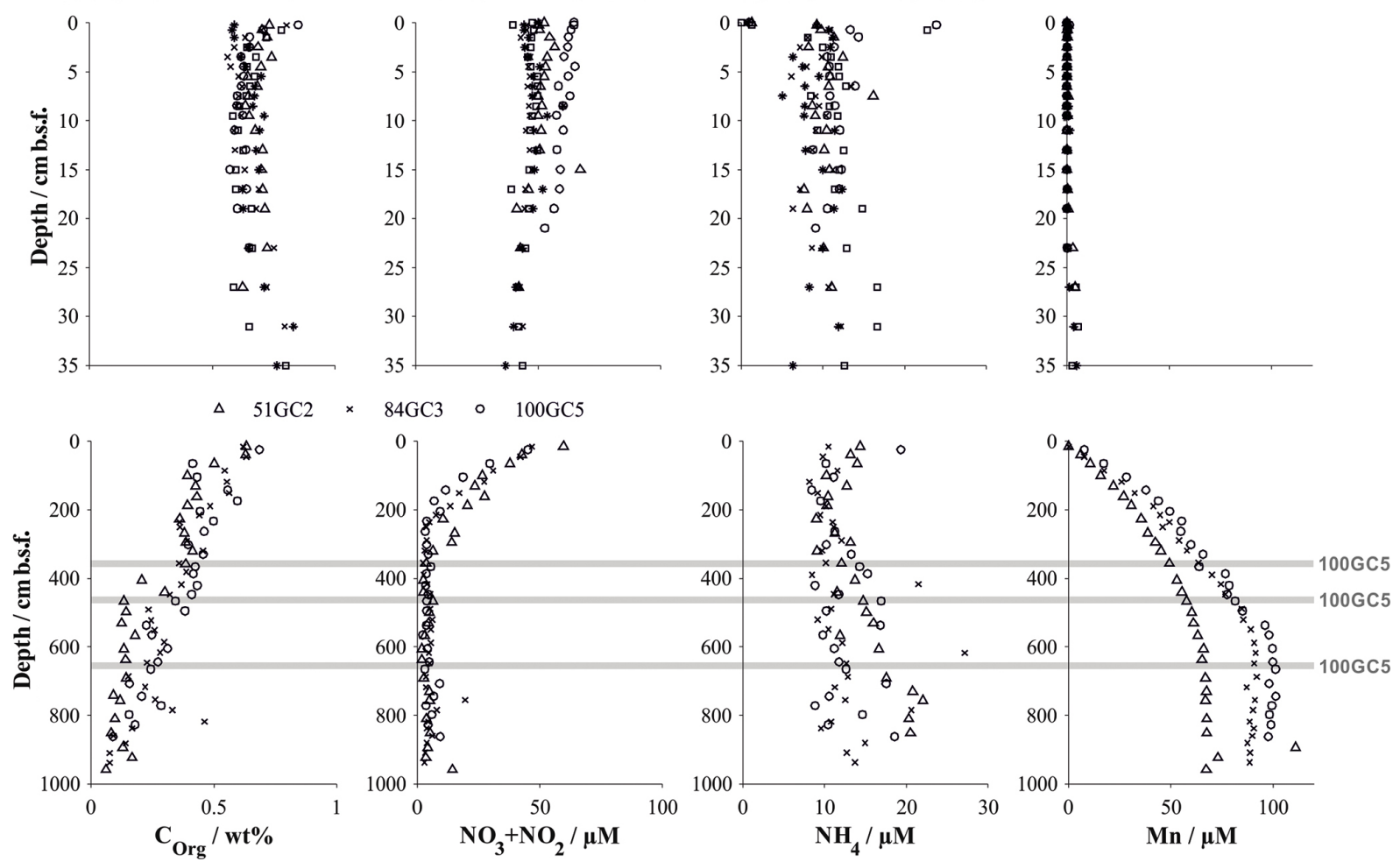

Figure 3. Organic carbon content (Paul et al., 2018, 2019) and dissolved solute profiles of summed $\mathrm{NO}_{3}$ and $\mathrm{NO}_{2}\left(\mathrm{Paul}_{\text {et }}\right.$ al., 2018, 2019), $\mathrm{NH}_{4}$ and $\mathrm{Mn}$ in gravity cores, and their corresponding multicores. Symbols represent the measured values at the mean depth of the sediment layer sampled. Buried manganese nodules are indicated by a grey line. Details on individual sampling stations can be found in Table 1. 
Table 3. Reaction stoichiometry and rate expressions of the organic mater $\left(\left(\mathrm{CH}_{2} \mathrm{O}\right)_{a}\left(\mathrm{NH}_{3}\right)_{\mathrm{b}}\left(\mathrm{H}_{3} \mathrm{PO}_{4}\right)_{c}\right)$ degradation and secondary redox reactions. All solute species are in concentrations of millimoles per litre of porewater $\left(\mathrm{mmol}_{\mathrm{pw}}^{-1}\right)$ and all solid species in millimoles per litre of dry sediment $\left(\mathrm{mmol} \mathrm{L}_{\mathrm{ds}}^{-1}\right)$. All reaction rate expressions are stated (in the units of $\left.\mathrm{mmol} \mathrm{L}_{\mathrm{pw}}^{-1} \mathrm{a}^{-1}\right)$ via a conversion with $F_{\mathrm{pw}}=\left(\frac{1-\phi}{\phi}\right)$.

\begin{tabular}{|c|c|}
\hline Reaction & Rate expression $\left(\mathrm{mmol} \mathrm{L}_{\mathrm{pw}}^{-1} \mathrm{a}^{-1}\right)$ \\
\hline \multicolumn{2}{|l|}{ Organic-matter degradation } \\
\hline $\begin{array}{l}\left(\mathrm{CH}_{2} \mathrm{O}\right)_{a}\left(\mathrm{NH}_{3}\right)_{\mathrm{b}}\left(\mathrm{H}_{3} \mathrm{PO}_{4}\right)_{c}+(a+2 b) \mathrm{O}_{2} \\
+(b+2 c) \mathrm{HCO}_{3}^{-} \rightarrow(a+b+2 c) \mathrm{CO}_{2} \\
+(b) \mathrm{NO}_{3}^{-}+(c) \mathrm{HPO}_{4}^{2-}+(a+2 b+2 c) \mathrm{H}_{2} \mathrm{O}\end{array}$ & $\sum_{i=1,2,3} k_{i} \frac{\operatorname{Corg}_{i}}{a} R_{\mathrm{O}_{2}} F_{\mathrm{pw}}$ \\
\hline $\begin{array}{l}\left(\mathrm{CH}_{2} \mathrm{O}\right)_{a}\left(\mathrm{NH}_{3}\right)_{\mathrm{b}}\left(\mathrm{H}_{3} \mathrm{PO}_{4}\right)_{c}+\left(\frac{4}{5} a+\frac{3}{5} b\right) \mathrm{NO}_{3}^{-} \\
\rightarrow \frac{1}{2}\left(\frac{4}{5} a+\frac{3}{5} b+b\right) \mathrm{N}_{2}+c \mathrm{HPO}_{4}^{2-} \\
+\left(\frac{3}{5} a+\frac{6}{5} b+2 c\right) \mathrm{H}_{2} \mathrm{O}+\left(\frac{1}{5} a-\frac{3}{5} b+2 c\right) \mathrm{CO}_{2} \\
+\left(\frac{4}{5} a+\frac{3}{5} b-2 c\right) \mathrm{HCO}_{3}^{-}\end{array}$ & $\sum_{i=1,2,3} k_{i} \frac{\operatorname{Corg}_{i}}{a} R_{\mathrm{NO}_{3}} F_{\mathrm{pw}}$ \\
\hline $\begin{array}{l}\left(\mathrm{CH}_{2} \mathrm{O}\right)_{a}\left(\mathrm{NH}_{3}\right)_{\mathrm{b}}\left(\mathrm{H}_{3} \mathrm{PO}_{4}\right)_{c}+2 a \mathrm{MnO}_{2}+(3 a+b-2 c) \mathrm{CO}_{2} \\
+(a+b-2 c) \mathrm{H}_{2} \mathrm{O} \\
\rightarrow(4 a+b-2 c) \mathrm{HCO}_{3}^{-}+2 a \mathrm{Mn}^{2+}+b \mathrm{NH}_{4}^{+} \\
+c \mathrm{HPO}_{4}^{2-}\end{array}$ & $\sum_{i=1,2,3} k_{i} \frac{\operatorname{Corg}_{i}}{a} R_{\mathrm{MnO}_{2}} F_{\mathrm{pw}}$ \\
\hline \multicolumn{2}{|l|}{ Secondary redox reactions } \\
\hline $\begin{array}{l}\mathrm{NH}_{4}^{+}+2 \mathrm{O}_{2}+2 \mathrm{HCO}_{3}^{-} \rightarrow \mathrm{NO}_{3}^{-}+2 \mathrm{CO}_{2}+3 \mathrm{H}_{2} \mathrm{O} k_{\mathrm{NH}_{4} \mathrm{Ox}} \mathrm{NH}_{4}^{+} \mathrm{O}_{2} \\
2 \mathrm{Mn}^{2+}+\mathrm{O}_{2}+4 \mathrm{HCO}_{3}^{-} \rightarrow 2 \mathrm{MnO}_{2}+4 \mathrm{CO}_{2}+2 \mathrm{H}_{2} \mathrm{O} \\
4 \mathrm{Fe}(\mathrm{II})+\mathrm{O}_{2}+2 \mathrm{H}_{2} \mathrm{O}+4 \mathrm{CO}_{2} \rightarrow 4 \mathrm{Fe}(\mathrm{III})+4 \mathrm{HCO}_{3}^{-}\end{array}$ & $\begin{array}{l}k_{\mathrm{MnOx}} \mathrm{Mn}^{2+} \mathrm{O}_{2} \\
k_{\mathrm{Fe}(\mathrm{II}) \mathrm{Ox}} \mathrm{Fe}^{2+} \mathrm{O}_{2}\end{array}$ \\
\hline \multicolumn{2}{|l|}{ Monod expressions } \\
\hline $\begin{array}{l}R_{\mathrm{O}_{2}}=\frac{\mathrm{O}_{2}}{K_{\mathrm{O}_{2}}+\mathrm{O}_{2}} s \\
R_{\mathrm{NO}_{3}}=\frac{\mathrm{NO}_{3}}{K_{\mathrm{NO}_{3}+\mathrm{NO}_{3}}} \frac{K_{\mathrm{O}_{2}}}{K_{\mathrm{O}_{2}}+\mathrm{O}_{2}} \\
R_{\mathrm{MnO}_{2}}=\frac{\mathrm{MnO}_{2}}{K_{\mathrm{Mn}}+\mathrm{MnO}_{2}} \frac{K_{\mathrm{NO}_{3}}}{K_{\mathrm{NO}_{3}}+\mathrm{NO}_{3}} \frac{K_{\mathrm{O}_{2}}}{K_{\mathrm{O}_{2}}+\mathrm{O}_{2}}\end{array}$ & \\
\hline
\end{tabular}

ules at depths of 4 to $8 \mathrm{~m}$ (Fig. 3). The undisturbed appearance of the sediment surrounding these buried nodules, and evidence of diagenetic alteration of the nodules, proves that these nodules were genuinely buried and do not represent a coring artefact.

In situ oxygen profiles confirm that the upper brown layer represents the oxygenated zone (Fig. 5). In this zone, oxic respiration of organic matter not only consumes downward diffusing oxygen but also increases ammonium and, via nitrification, nitrate (Fig. 6). While the trend in the nitrate profiles is clearly discernable, ammonium concentrations remain rather low (10-20 $\left.\mathrm{mol} \mathrm{L}^{-1}\right)$ and are scattered and likely controlled by secondary processes, such as adsorption and desorption (Haeckel et al., 2001). Below the oxic dark brown layer, denitrification commences and nitrate declines within the upper $2-3 \mathrm{~m}$ of the sediment and is entirely depleted in the cores with the greyish green $\mathrm{Fe}(\mathrm{II})$-rich reaction layer (51GC2, 84GC3, 100GC5, 123GC6; Fig. 3). The depleted nitrate profiles tend to be more linear (e.g. 84GC3) than the profiles of cores where the $\mathrm{Fe}(\mathrm{II})$-rich layer is absent (e.g. 132GC7), as is typical in the presence of a reaction layer (Goloway and Bender, 1982; Wilson et al., 1985; Jahnke et al., 1989). Dissolved manganese is strongly redox sensitive and is absent in the upper oxic zone (Fig. 6). Below the oxic zone, organic-matter degradation progresses to manganese oxide reduction and produces dissolved manganese, which increases steadily until it reaches an asymptotic concentration at $6 \mathrm{~m}$ depth, with terminal concentrations ranging between 25 and $120 \mu \mathrm{mol} \mathrm{L}^{-1}$ (Fig. 3). Diagenetic simulations (Haeckel et al., 2001) could not reproduce this strong increase in dissolved manganese, and the discovery of buried manganese nodules now confirms that the dissolved manganese concentrations are indeed additionally shaped by the dissolution of manganese nodules at a depth of 4-8 m.

Alkalinity profiles are largely unchanged over the entire sampling domain (up to $10 \mathrm{~m}$ ) but display some variations in the upper $5 \mathrm{~cm}$ (Fig. 6). Haeckel et al. (2001) have argued that the alkalinity profile is likely influenced by carbonate geochemistry, so we will neglect the upper alkalinity profile in our interpretations. Dissolved iron concentrations were near 
Table 4. Constrained and fitted parameters used in the numerical simulations.

\begin{tabular}{|c|c|c|c|}
\hline Parameter & Value & Units & Reference \\
\hline \multicolumn{4}{|l|}{ General parameter } \\
\hline Temperature & 4 & ${ }^{\circ} \mathrm{C}$ & (a) \\
\hline Pressure & 400 & bar & (a) \\
\hline Salinity & 35 & $\%$ & (a) \\
\hline Redfield ratio $(\mathrm{C}: \mathrm{N}: \mathrm{P})$ & $106: 16: 01$ & & \\
\hline Sedimentation rate & 0.0004 & $\mathrm{~cm} \mathrm{a}^{-1}$ & Haeckel et al. (2001) \\
\hline Maximum depth of calculation & 200 & $\mathrm{~cm}$ & \\
\hline Number of points in the numerical grid (uneven) & 500 & & \\
\hline \multicolumn{4}{|l|}{ Fitted parameters - background (reference) model } \\
\hline Porosity at sediment surface $\left(\varphi_{0}\right)$ & 0.94 & & (c) \\
\hline Porosity at infinite depth $\left(\varphi_{\infty}\right)$ & 0.86 & & (c) \\
\hline Porosity attenuation coefficient $(\beta)$ & 0.14 & & (c) \\
\hline Bioturbation coefficient $\left(D_{\mathrm{b}}^{0}\right)$ & 0.65 & $\mathrm{~cm}^{2} \mathrm{a}^{-1}$ & (b) \\
\hline Bioturbation half-depth $\left(x_{D_{\mathrm{b}}}\right)$ & 10 & $\mathrm{~cm}$ & (b) \\
\hline Bioturbation decrease $\left(\beta_{D_{\mathrm{b}}}\right)$ & 4 & & (b) \\
\hline Flux of labile $C_{\text {org }}\left(F_{\mathrm{G} 0}\right)$ & 10 & $\mu \mathrm{mol} \mathrm{cm} \mathrm{cm}^{-2} \mathrm{a}^{-1}$ & (c) \\
\hline Flux of semi-labile $C_{\mathrm{org}}\left(F_{\mathrm{G} 1}\right)$ & 1.2 & $\mu \mathrm{mol} \mathrm{cm}{ }^{-2} \mathrm{a}^{-1}$ & (c) \\
\hline Flux of refractory $C_{\mathrm{org}}\left(F_{\mathrm{G} 2}\right)$ & 0.06 & $\mu \mathrm{mol} \mathrm{cm} \mathrm{cm}^{-2} \mathrm{a}^{-1}$ & (c) \\
\hline Rate constant for labile $C_{\text {org }}$ oxidation $\left(k_{\mathrm{G} 0}\right)$ & 0.1 & $a^{-1}$ & (c) \\
\hline Rate constant for semi-labile $C_{\text {org }}$ oxidation $\left(k_{\mathrm{G} 1}\right)$ & 0.003 & $a^{-1}$ & (c) \\
\hline Rate constant for refractory $C_{\text {org }}$ oxidation $\left(k_{\mathrm{G} 2}\right)$ & $5 \times 10^{-7}$ & $a^{-1}$ & (c) \\
\hline Rate constant for reaction of $\mathrm{Mn}^{2+}$ and $\mathrm{O}_{2}$ & $1 \times 10^{+6}$ & $\mathrm{~L} \mathrm{mmol}^{-1} \mathrm{a}^{-1}$ & (c) \\
\hline Rate constant for reaction of $\mathrm{NH}_{4}^{+}$and $\mathrm{O}_{2}$ & 500 & $\mathrm{~L} \mathrm{mmol}^{-1} \mathrm{a}^{-1}$ & (c) \\
\hline Monod constant for $\mathrm{O}_{2}$ reduction & $8 x^{-6}$ & mmol & (c) \\
\hline Monod constant for $\mathrm{NO}_{3}^{-}$reduction & 0.03 & mmol & Boudreau (1996) \\
\hline Monod constant for $\mathrm{MnO}_{2}$ reduction & 10 & mmol & Boudreau (1996) \\
\hline$\left[\mathrm{MnO}_{2}\right]_{\text {model domain }}$ & 1.9 & wt $\%$ & (a) \\
\hline$\left[\mathrm{O}_{2}\right]_{\text {bottom water }}$ & 0.132 & $\mathrm{mmol} \mathrm{L}^{-1}$ & (a) \\
\hline$\left[\mathrm{NO}_{3}^{-}\right]$bottom water & 0.042 & $\mathrm{mmol} \mathrm{L}^{-1}$ & (a) \\
\hline$\left[\mathrm{NH}_{4}^{+}\right]_{\text {bottom water }}$ & 0 & $\mathrm{mmol} \mathrm{L}^{-1}$ & (a) \\
\hline$\left[\mathrm{Mn}^{2+}\right]_{\text {bottom water }}$ & 0 & $\mathrm{mmolL}^{-1}$ & (a) \\
\hline [Alkalinity $]_{\text {bottom water }}$ & 2.4 & meq $L^{-1}$ & (a) \\
\hline$\left[\mathrm{Mn}^{2+}\right]_{\text {lower boundary }}$ & 0.05 & $\mathrm{mmolL}^{-1}$ & (a) \\
\hline \multicolumn{4}{|l|}{ Parameter for impact simulations } \\
\hline Bioturbation recovery time $\left(t D_{B}\right)$ & $100 / 200$ & $\mathrm{a}$ & (d) \\
\hline \multicolumn{4}{|l|}{ Case "reactive $\mathrm{Fe}(\mathrm{II})-\mathrm{O}_{2}$ layer" } \\
\hline$[\mathrm{Fe}(\mathrm{II})]$ at lower boundary & 0.44 & wt $\%$ & (e) \\
\hline $\mathrm{Fe}(\mathrm{II})$ half-depth of increase & 20 & $\mathrm{~cm}$ & \\
\hline $\mathrm{Fe}(\mathrm{II})$ profile reduction coefficient & 2 & & \\
\hline Rate constant for reaction of $\mathrm{Fe}(\mathrm{II})$ and $\mathrm{O}_{2}$ & 100 & $\mathrm{Lmmol}^{-1} \mathrm{a}^{-1}$ & (c) \\
\hline \multicolumn{4}{|l|}{ Case "removal" } \\
\hline Removed sediment thickness & 10 & $\mathrm{~cm}$ & (d) \\
\hline \multicolumn{4}{|l|}{ Case " $\mathrm{O}_{2}$ flooding" } \\
\hline$\left[\mathrm{O}_{2}\right]_{\text {reactive layer }}$ & $=\left[\mathrm{O}_{2}\right]_{\text {bottom water }}$ & $\mathrm{mmol} \mathrm{L}^{-1}$ & \\
\hline Half-depth $\mathrm{O}_{2}$ decrease & 12 & $\mathrm{~cm}$ & \\
\hline $\mathrm{O}_{2}$ attenuation coefficient & 2.5 & & \\
\hline \multicolumn{4}{|l|}{ Bioturbation model } \\
\hline${ }^{210} \mathrm{~Pb}$ radioactive decay constant & $\ln (2) / 22.3$ & $a^{-1}$ & \\
\hline${ }^{226} \mathrm{RaTh}$ radioactive decay constant & $\ln (2) / 1602$ & $a^{-1}$ & \\
\hline${ }^{230} \mathrm{Th}$ radioactive decay constant & $\ln (2) / 57380$ & $a^{-1}$ & \\
\hline$[210 \mathrm{~Pb}]_{\text {bottom water }}$ & 1.0 & $\mathrm{Bqg}^{-1}$ & (b) \\
\hline$\left[{ }^{226} \mathrm{Ra}\right]_{\text {bottom water }}$ & 0.3 & $\mathrm{Bqg}^{-1}$ & (b) \\
\hline$\left[{ }^{230} \mathrm{Th}\right]_{\text {bottom water }}$ & 0.6 & $\mathrm{~Bq}^{-1}$ & (b) \\
\hline
\end{tabular}

(a) Approximated by field data. (b) Fitted to Pb data (Fig. 7). (c) Fitted to field data. (d) Approximated from data and references presented in Volz et al. (2020). (e) Inferred from data presented in König et al. (1997, 1999). 

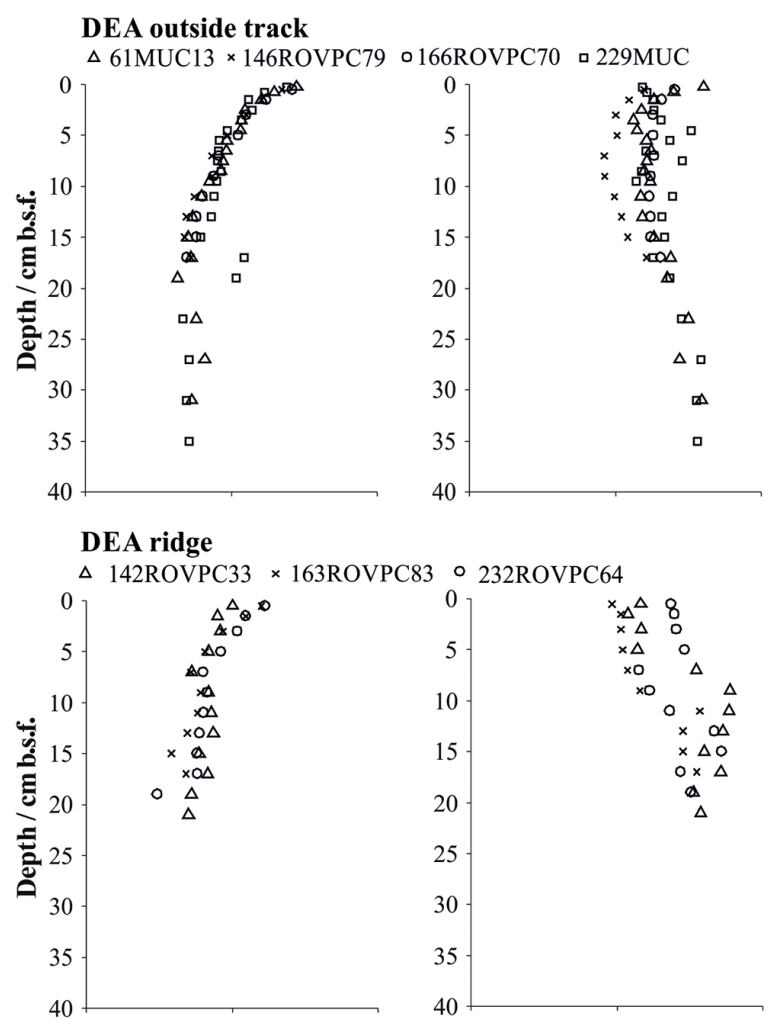

EBS track

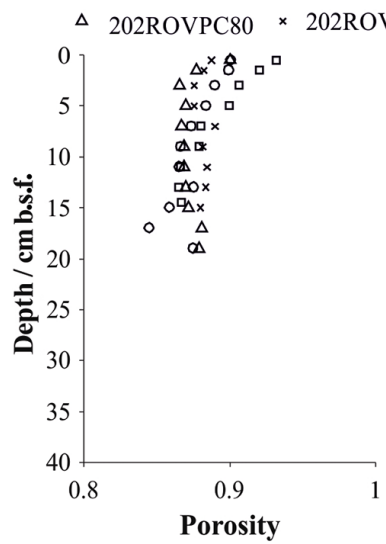

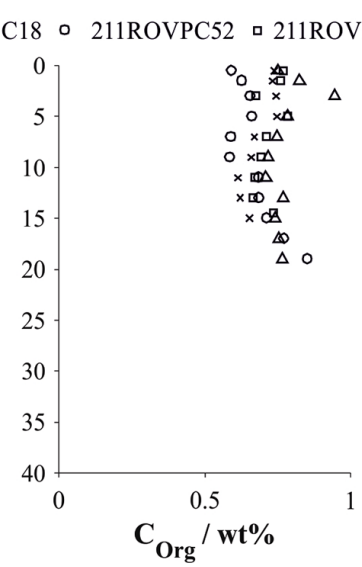

DEA furrow

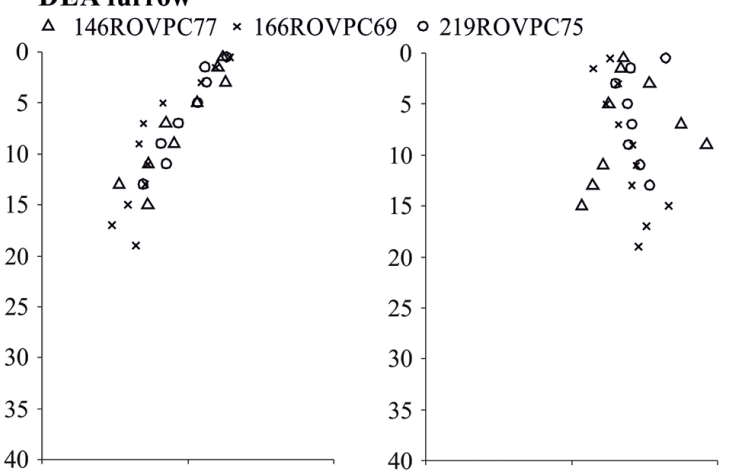

DEA subsurface patch
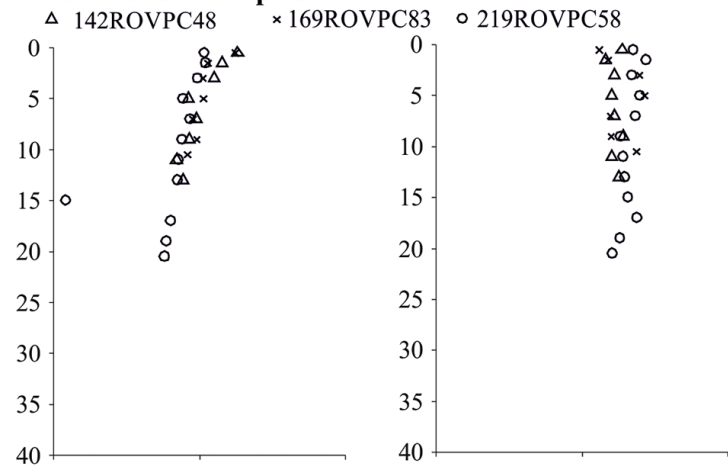

\section{Reference}
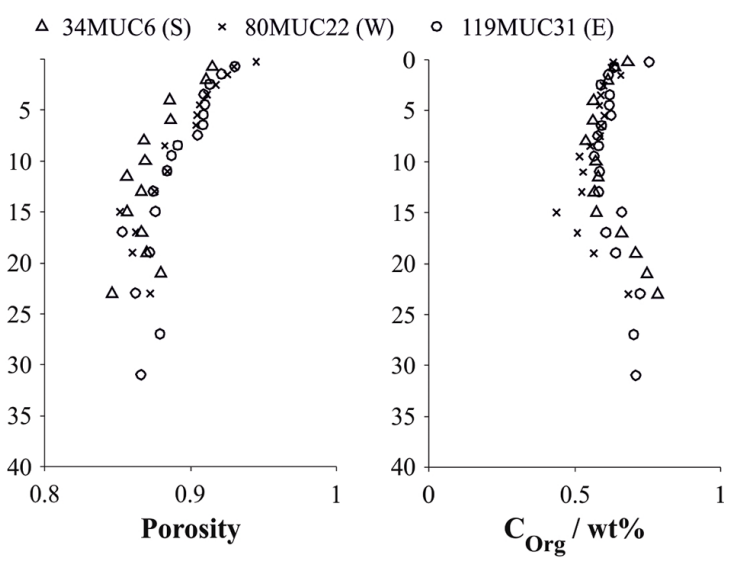

Figure 4. Porosity and organic carbon content in multiple and box cores retrieved in various microhabitats (Paul et al., 2018). Symbols represent the measured values at the mean depth of the sediment layer sampled. Details on individual sampling stations can be found in Table 1.

or below the detection limit of $1 \mu \mathrm{M}$ in all cores due to its incorporation into the clay mineral phase, and sulfate concentrations remained close to their sea water value, which is in line with the absence of sulfate reduction in the Peru Basin.

\subsection{Diagenetic reference model}

With the MiningImpact sampling campaign specifically targeting the DEA region, we were able to update the parameterization of the previous model presented by Haeckel et al. (2001). The main differences are as follows. (i) The pre- sented model applies a 3G model, i.e. allows for three fractions of organic matter with varying reactivity and thus a better fit to the field data. (ii) The bioturbation intensity $\left(D_{\mathrm{b}}=\right.$ $\left.0.65 \mathrm{~cm}^{2} \mathrm{a}^{-1}\right)$ and depth profile are now based on radioactive disequilibria between radionuclides of the natural uranium and thorium series in the DEA region (Fig. 7). The numerical simulations predict that excess ${ }^{210} \mathrm{~Pb}$ (difference between solid and dashed lines) exists down to $\sim 10 \mathrm{~cm}$ and below the measured activity is supported by ${ }^{230} \mathrm{Th}$ (dotted line) and ${ }^{226} \mathrm{Ra}$ (difference between dashed and dotted lines). A rel- 

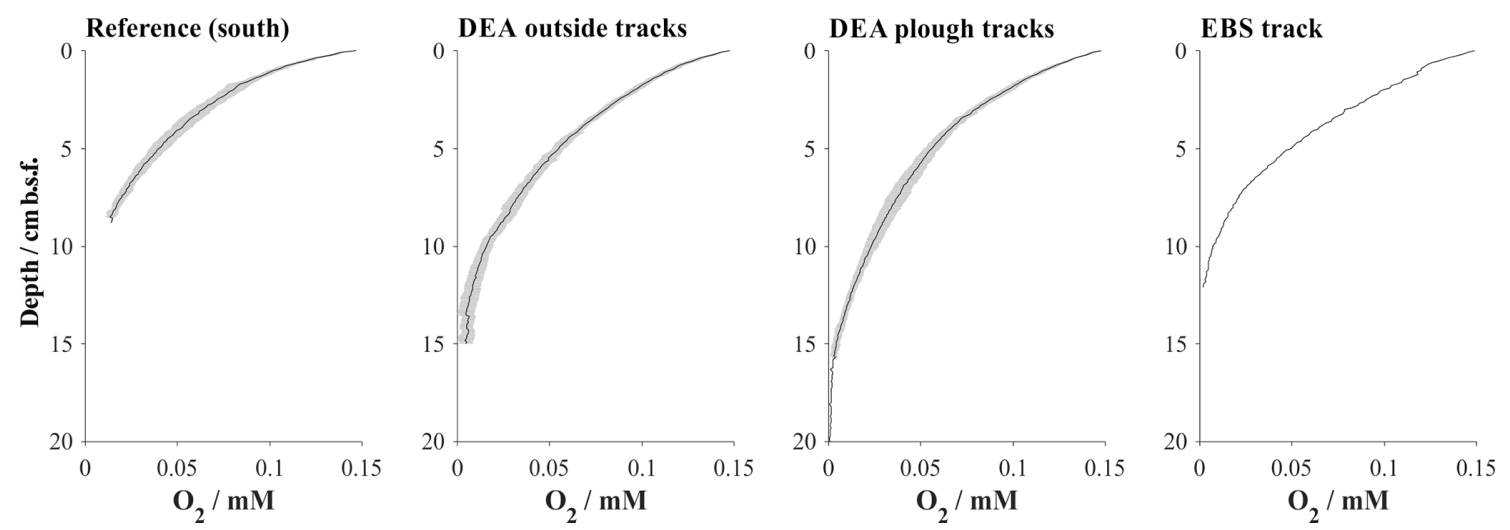

Figure 5. Averaged (black line) in situ oxygen profile representative of various disturbance settings including their standard deviations (shaded area). Because the depth steps between each measuring point of the oxygen profiles are very close, they are not resolved in the diagram. Details on individual sampling stations can be found in Table 1.

atively high scatter of radioactive activities of $1.5-3 \mathrm{~Bq} \mathrm{~g}^{-1}$ was observed in the uppermost sediment samples $(0-0.5 \mathrm{~cm})$, reflecting lateral inhomogeneities. These could be due to sediment focusing created by local topography, e.g. small depressions acting as deposition centres for fluffy material, or by "hotspots" of non-local mixing by individual organisms.

A satisfactory background model fit to undisturbed reference sites could be achieved for all relevant parameters, with particular focus being placed on accurately simulating the redox zonation of the sediment, especially the oxygen penetration depth and the concurrent increase in dissolved manganese (Fig. 8). It should be noted that the geochemical state of the Peru Basin is likely transient in nature, arising from long-term (glacial and interglacial) as well as shortterm (ENSO timescale) variations in the depositional flux of organic matter (König et al., 2001). This work focuses on modelling the biogeochemical processes in the upper halfmetre of the sediment; these are defined by the Holocene organic-matter input and are thus unaffected by long-term changes in the depositional flux. Similar to the downwardmigrating nitrate front, it is likely that the pore water oxygen content also increases with currently waning organic-matter input. The analytical oxygen profiles display less curvature (more linearity) than the modelled profiles, which suggests that secondary reactions, such as a semi-labile Fe(II)-oxygen reaction front, additionally shape the oxygen profile. However, due to the uncertainty in a transient parameterization, we model the reference sediments as a steady-state scenario - justified by the generally good agreement of the model with the geochemical data.

\subsection{Impact characterization}

All sample stations were affected by at least one of the following processes: (i) removal of the upper dark brown reactive layer, (ii) mixing and redistribution of the surface sediment, resulting in piling up ("ridges") and removal ("fur- rows"), (iii) turning of the upper sediment upside down or bringing up deep sediment to the surface - both leading to exposure of sediment from below the reactive layer at the surface, and (iv) deposition of resuspended sediment. Furthermore, there were distinct differences in the physical impact of the plough-harrow and EBS track. While the EBS scraped off the surface sediments and relocated them to the side of the track, the plough-harrow mixed and displaced sediments, resulting in a variety of disturbance structures. In the following a detailed description of the physical and geochemical impact is provided and will be complemented by information on the microbiological impact from a parallel study (Vonnahme et al., 2020).

Sediments inside the EBS track are largely devoid of the upper reactive brown layer, exposing the tan-coloured subsurface sediment in places. The surface of the track is smooth, indicating that sediment mixing is negligible inside the tracks. Removal of the upper reactive layer resulted in decreased sediment porosity by exposing more compacted sediment compared to the reference sites and brought the boundary below which dissolved manganese is found in the sediment pore water as close as $5 \mathrm{~cm}$ b.s.f. (Figs. 4 and 6). In contrast, the oxygen penetration depth does not vary significantly from the reference area; the profile shape is, however, slightly more linear (Fig. 5). In line with the severe disturbance of the sediment, physical signs of bioturbation (recent bioturbation channels connected to the surface) are lacking and the microbial cell count in the surface sediment is reduced by $50 \%$, with the microbial communities being significantly different from the reference sites (Vonnahme et al., 2020). 

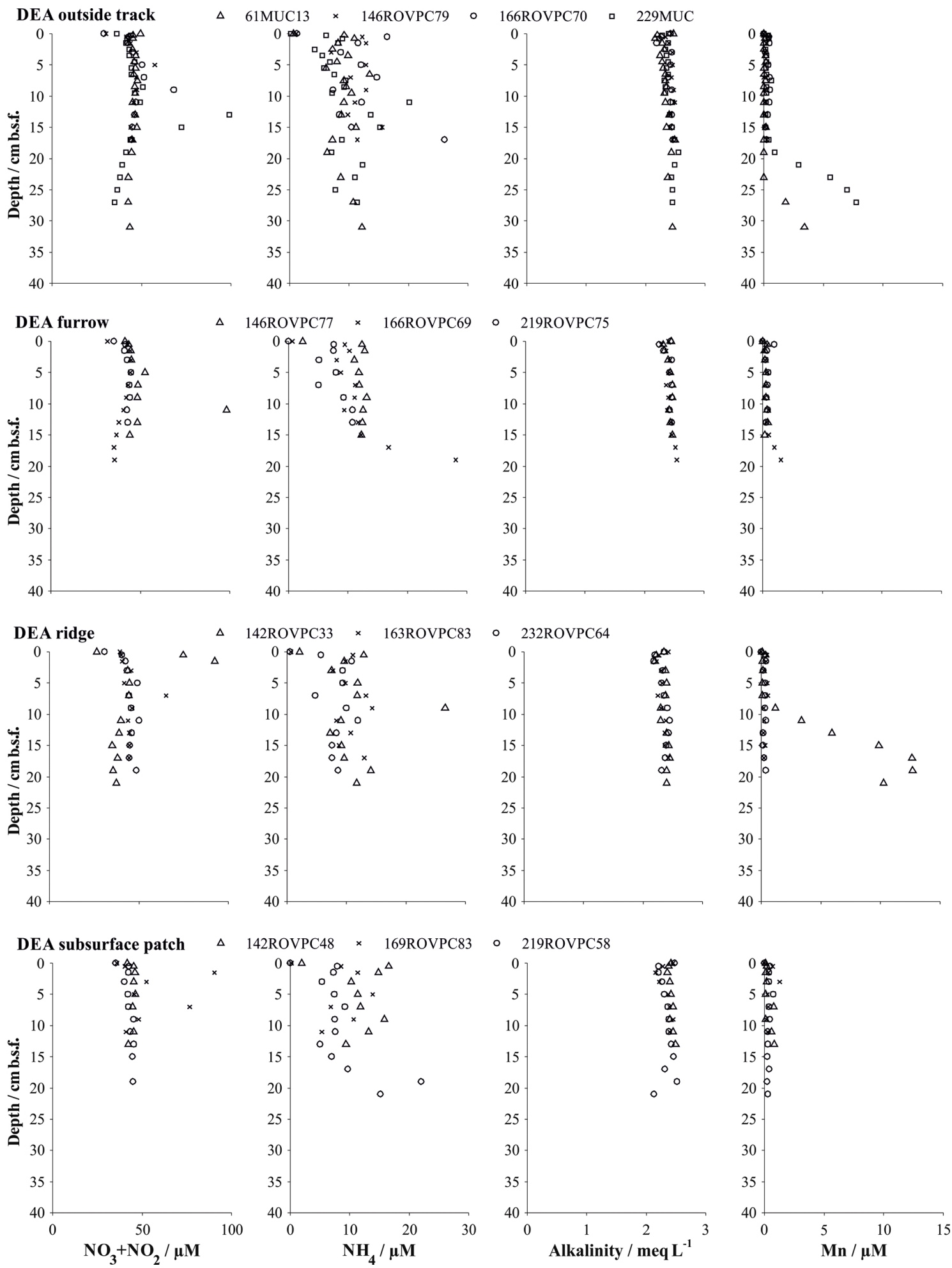

Figure 6. 

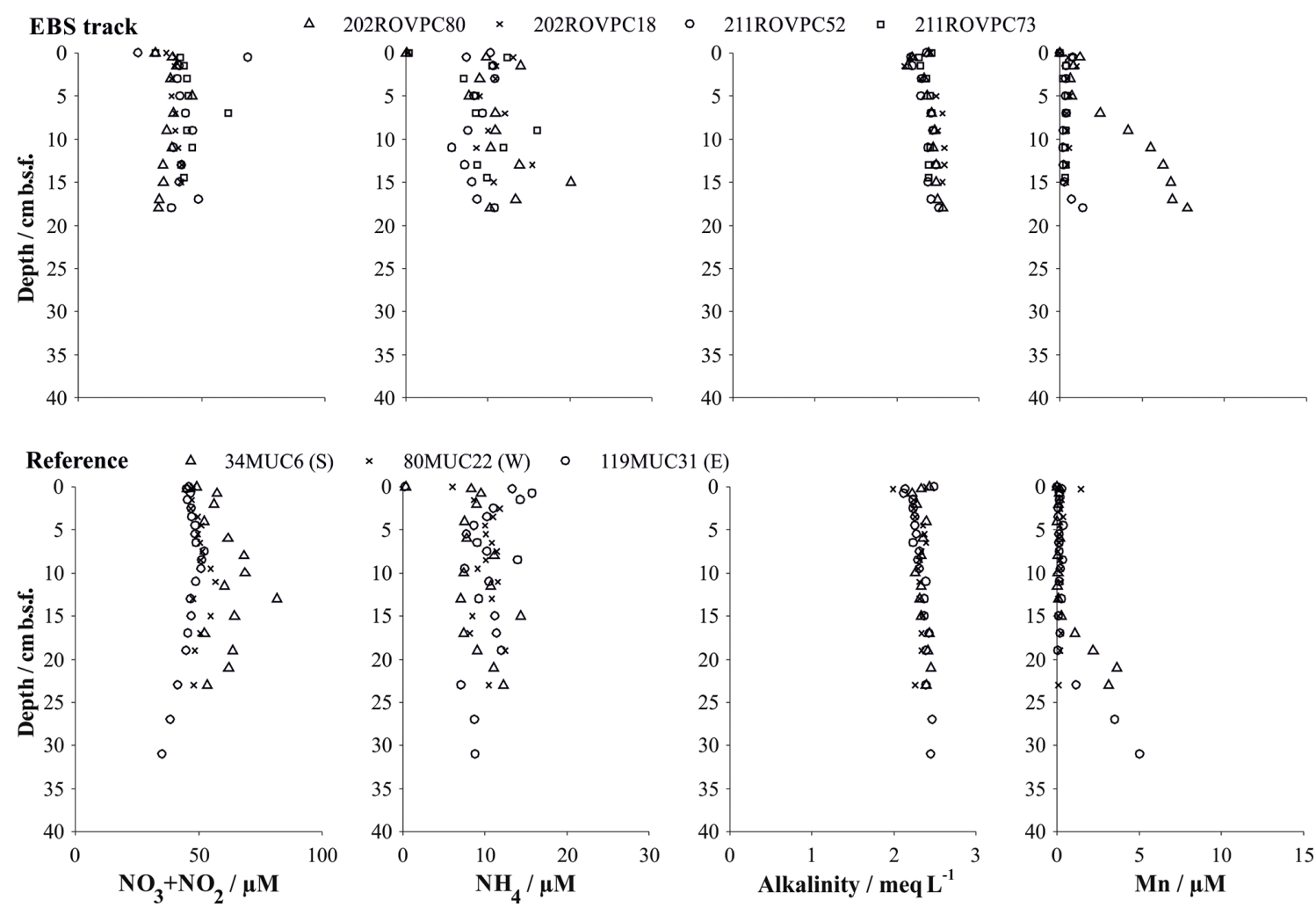

Figure 6. Solute profiles in multiple and box cores retrieved in various microhabitats. Symbols represent the measured values at the mean depth of the sediment layer sampled (summed $\mathrm{NO}_{3}$ and $\mathrm{NO}_{2}$ from Paul et al., 2018). Details on individual sampling stations can be found in Table 1.
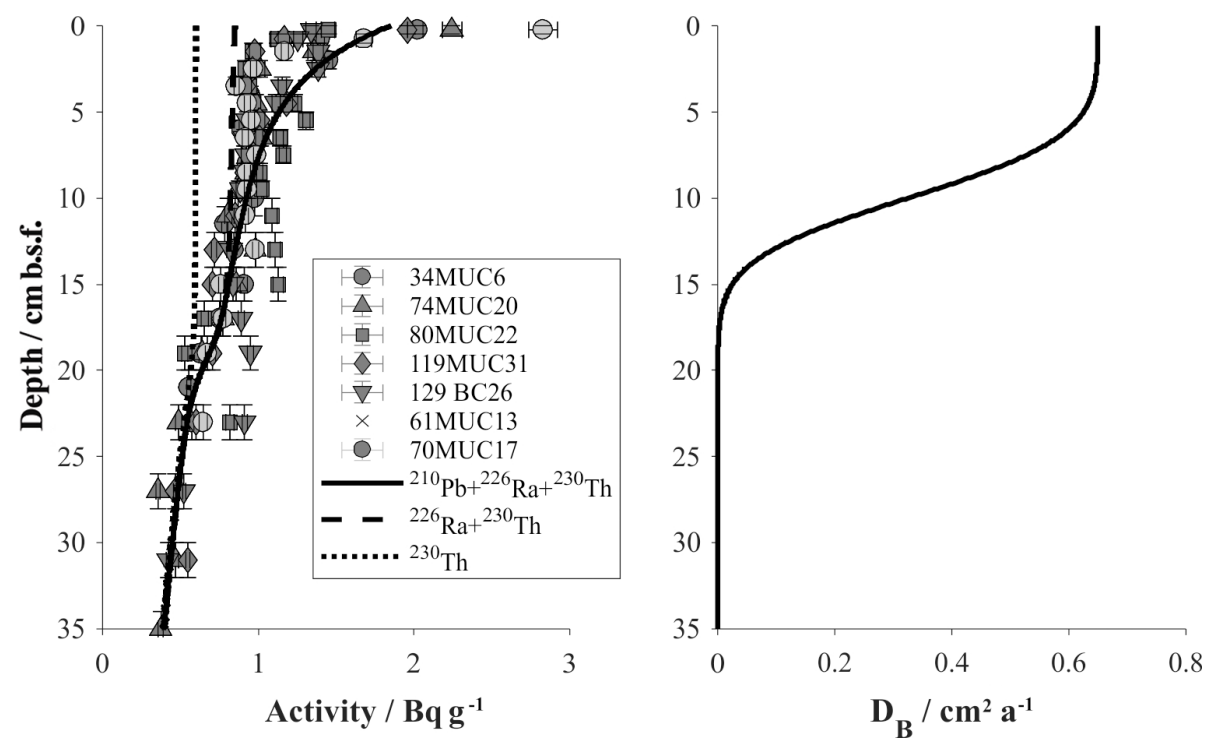

Figure 7. Model results of the faunal bioturbation activity in reference and DEA outside track sediments based on measured ${ }^{210} \mathrm{~Pb}$ activities. Left: model curves indicate total ${ }^{210} \mathrm{~Pb}$ activity (solid) and supported contributions by ${ }^{230} \mathrm{Th}$ (dotted) and ${ }^{226} \mathrm{Ra}$ (dashed). Right: bioturbation intensity profile derived for the background model. 
The disturbance of the surface sediment layer brought about during the DISCOL experiment was still clearly visible after 26 years, and the TV-guided sampling campaign was able to specifically target the following features. (i) The area next to the plough-harrow track (outside track) is not mechanically disturbed but affected by resettling sediment from the disturbance plume. Geochemical profiles do not indicate a significant difference to the reference site (Fig. 6), especially with the natural heterogeneity of the area in mind. Differences in the microbial functions compared to the reference stations are also within the methods' confidence level, and recent bioturbation confirms that the sediment is presently colonized by burying macrofauna (Vonnahme et al., 2020). (ii) The furrows drawn in the seabed by the plough-harrow show some distinct differences to the reference sites. The reactive dark brown surface layer is reduced in thickness and is overlain by resettling sediment which preferentially accumulated in the depression. While geochemical profiles do not differ significantly from the reference site, biological processes are noticeably decreased (Vonnahme et al., 2020). (iii) Ridge sediments show the same disturbance effects, albeit more severe, and seafloor integrity is compromised by deep cracks throughout the sediment (Vonnahme et al., 2020). (iv) Exposed subsurface sediment observable as lighter-coloured patches shows the highest level of disturbance, similar in character to the fresh surface created by the EBS. The reactive brown layer is absent, and thus the porosity of the surface sediment reduced (Fig. 4). Biological processes are significantly impacted. Bioturbation channels are scarce and disconnected with the surface, indicating a preimpact origin. Microbial cell numbers are reduced by $30 \%$, with the microbial communities being more similar to those of the subsurface sediment (14-16 cm b.s.f.) of the reference stations than those of the surface sediments (Vonnahme et al., 2020).

\subsection{Prognostic simulations}

The following presentation of simulation results focuses on the distribution of oxygen, which plays a central role in biogeochemical processes: different impact types were simulated by two "endmember" scenarios. The first scenario assumes that $10 \mathrm{~cm}$ of the upper sediment were removed; i.e. the first $10 \mathrm{~cm}$ of the reference steady-state profiles were discarded, exposing anoxic subsurface sediments to bottom water concentrations. The second scenario floods the upper $10 \mathrm{~cm}$ of the sediment with oxygen, representing, on the one hand, the effect of sediment mixing and cracking and, on the other, the effect of resuspension and subsequent settling of freshly oxygenated reactive sediment (Fig. 9). The transient models showed that the impact of the removal of the reactive upper $10 \mathrm{~cm}$ layer is much more severe and longer lasting compared to the "oxygen flooding" scenario. And simulations show no distinguishable difference if 8 or $12 \mathrm{~cm}$ is removed instead of 10 . This is because the greatest disturbance effect is caused by the absence of the labile organic-matter fraction, which is restricted mostly to the upper $10 \mathrm{~cm}$ of the sediment.

\section{Short-term impact}

Immediately after the removal of the highly reactive surface sediment, solute profiles are in strong disequilibrium and mostly diffusion controlled. This is especially true for oxygen, which rapidly diffuses into previously anoxic sediments. The Fe(II) layer plays an insignificant role in the initial postimpact weeks but commences to inhibit further penetration of the oxygen front at 5 weeks. In the absence of the reactive surface layer, organic-matter degradation rates, which strongly shape the reference oxygen profile, play only a minimal role in the weeks after the disturbance. The modelled "removal" profiles agree well with the analytical in situ oxygen profiles of the 5-week-old EBS track and confirm that the linear nature of the analytical profiles is likely shaped by a mixture of a downward-diffusing oxygen front and the initiation of the oxygen-Fe(II) reaction layer. For comparison, impact simulations assuming full recovery of the bioturbation intensity by 200 years instead of 100 years are also shown. Here, the oxygen profile is also distinctly more linear, but even more reduced sediment mixing through bioturbation allows oxygen to penetrate slightly deeper $(18 \mathrm{~cm}$ b.s.f.) compared to the in situ oxygen profiles $(13 \mathrm{~cm})$ and to the 100 -year bioturbation recovery interval $(10 \mathrm{~cm}$ b.s.f, Fig. 10$)$.

The oxygen flooding scenario produces a very different oxygen profile. It is shaped mainly by the reaction of the anomalous oxygen with the reactive (labile) organic matter, especially in the upper centimetres, where the labile organic matter is most concentrated. The difference to the EBS track in situ profiles supports the observation that the EBS track is mainly affected by sediment removal rather than mixing (Fig. 11).

\section{Medium-term impact}

The existence of the Fe(II)-oxygen reaction layer plays a particularly important role in the decades after the disturbance. Oxygen is less efficiently removed from the pore water in both scenarios: removal of the reactive layer significantly reduces oxygen uptake through organic-matter degradation, and the reactivity of the organic matter was reduced due to reaction with the anomalous flooding with oxygen. In the absence of an oxygen-impeding reaction layer, oxygen penetration depths would consequently be significantly increased in both cases (Figs. 10 and 11). Simulating the 26year-old DISCOL disturbance has shown that the existence of an oxygen-consuming reaction layer is a necessary prerequisite. The removal scenario produces slightly more linear profiles compared to the oxygen flooding simulation because of the relative importance of the $\mathrm{Fe}$ (II)-oxygen reaction layer over the organic-matter degradation process. The slight mis- 

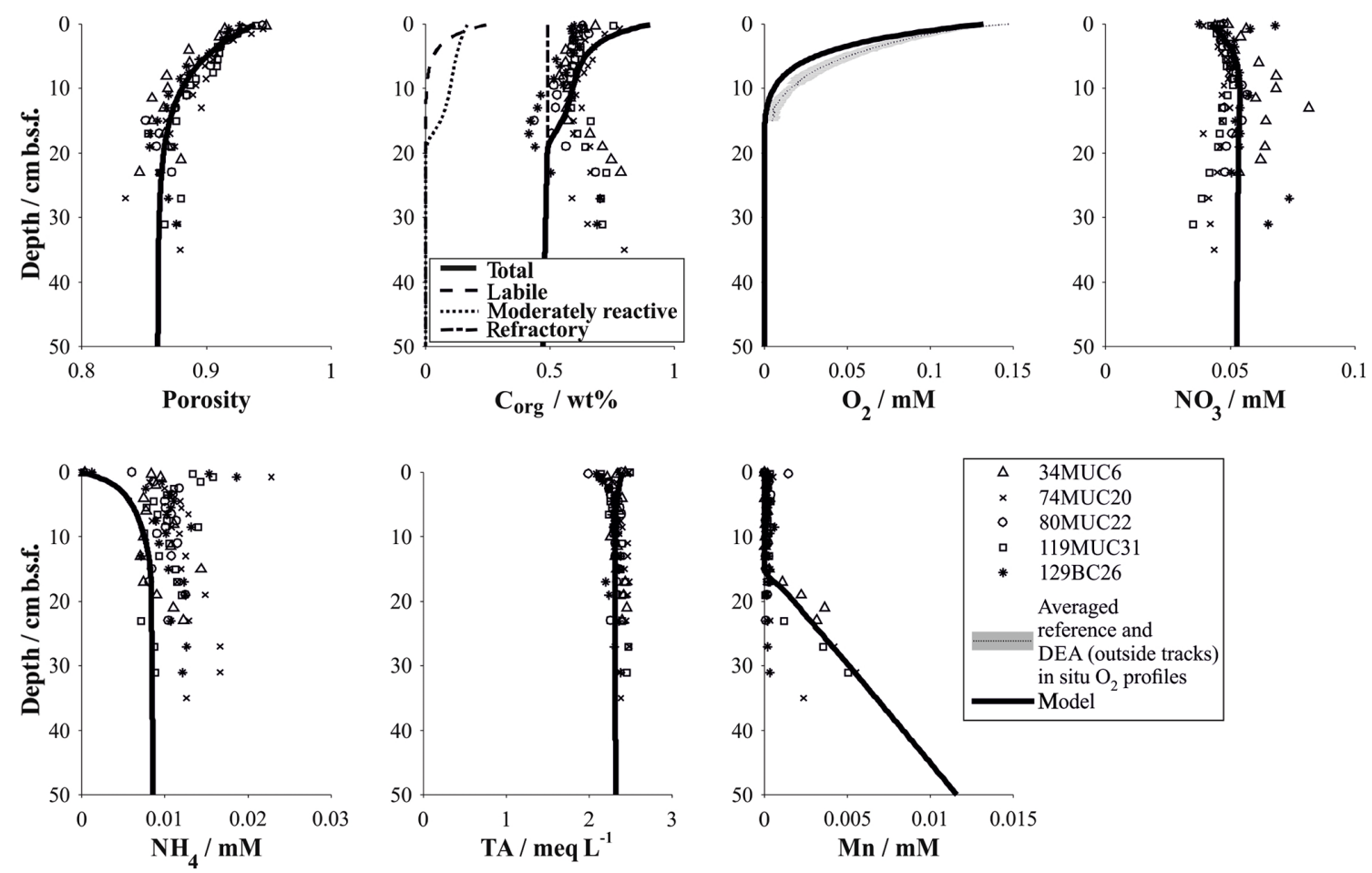

Figure 8. Simulation of background biogeochemical processes and their effect on solute profiles in the DEA region. In addition to the three reference stations, two other undisturbed sites were included for comparison. See Table 4 for parameterization of the modelled profiles.

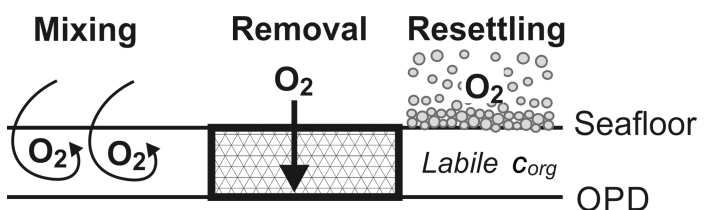

Semi-labile corg and semi-labile Fe(II)

Figure 9. Schematic characterization of the different impact types at a mined seafloor and their influence on $\mathrm{O}_{2}$ distribution.

fit of both scenarios with the in situ oxygen data suggests that the DEA tracks are most likely affected by a mixture of both scenarios, possibly levelled out by lateral diffusion effects. Ongoing organic-matter flux at the surface sediment builds up a new post-impact reactive layer with reactivities higher than in the reference model due to the ineffective mixing into deeper sediments through bioturbation (Figs. 10 and 11). Thus, differences between bioturbation recovery scenarios, i.e. 100 and 200 years, increase over time with an increasing amount of fresh organic matter that can potentially be mixed into the sediment.

\section{Long-term impact}

It takes centuries for the geochemical processes to completely recover after the removal of the upper reactive sediment. While the observed geochemical profiles of the dis- turbed sites show surprisingly little variation compared to the reference site, overall surface fluxes vary significantly during the first 100 years after the impact. This is especially true for the oxygen flux into the sediment, which is more than halved within the first year of the impact (Fig. 10). Within the first decades after the impact, the build-up of the labile organic matter, and its mixing into deeper sediment through bioturbation, gains influence. With increasing depletion of oxygen through organic-matter degradation, oxygen concentrations decrease along with $\mathrm{Fe}(\mathrm{II})$-oxygen reaction rates. The transition from $\mathrm{Fe}$ (II)-controlled to organic-matter-controlled oxygen profiles is accompanied by a slight increase in the oxygen penetration depth (Fig. 10). The exact quantification of this transition is difficult to estimate, but the fact that 26 years after the impact oxygen profiles are still efficiently impeded by the $\mathrm{Fe}(\mathrm{II})$-oxygen reaction layer suggests that this process will significantly reduce the oxygen penetration depth until the organic-matter degradation rates are near pre-disturbance levels (ca. 100 years after the impact). Interestingly, while steady-state biogeochemical processes strongly depend on the depth and intensity of bioturbation (Haeckel et al., 2001), the time frame of the bioturbation recovery has very little influence on the overall impact recovery process (Fig. 10). This is due to the fact that the limiting factor is the availability of labile organic matter, which is replenished on a much longer timescale compared to the faunal recovery (Stratmann et al., 2018a). 

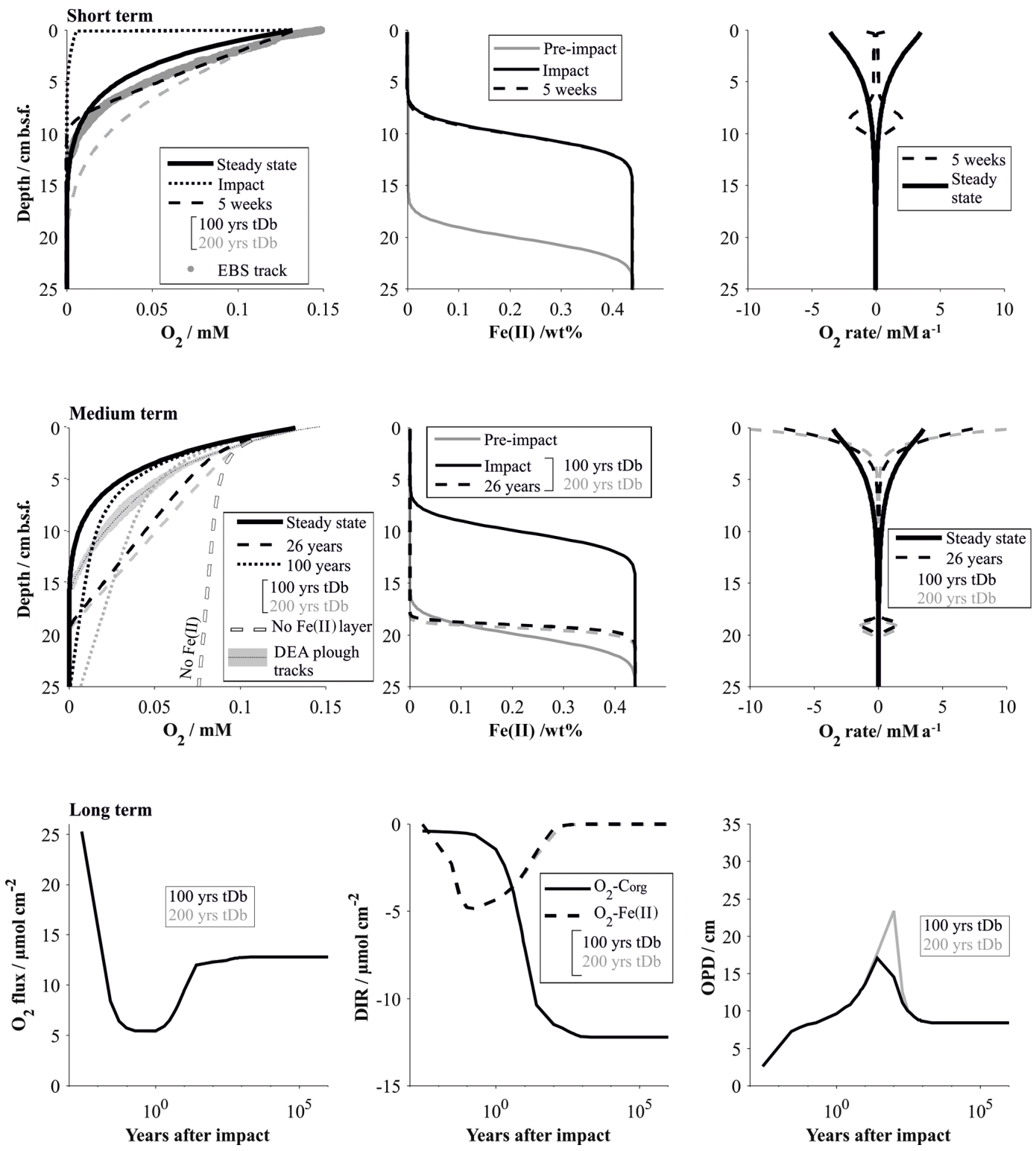

Figure 10. Impact simulations after a disturbance that causes the reactive upper $10 \mathrm{~cm}$ to be removed. The short-term (up to 5 weeks, comparable to the EBS tracks) and medium-term (26 years, comparable to the DEA tracks) impacts are visualized by the respective $\mathrm{O}_{2}$ profiles and the fluxes shaping the $\mathrm{O}_{2}$ profiles. It is assumed that the oxygen penetration depth is impeded by a reactive Fe(II) layer. Note that the $\mathrm{Fe}(\mathrm{II})$ is assumed to be located at $20 \mathrm{~cm}$ b.s.f. but is placed at $10 \mathrm{~cm}$ if the upper $10 \mathrm{~cm}$ is removed. For comparison the $\mathrm{O}_{2}$ profile in the absence of a Fe(II) layer is also shown. The long-term impact is demonstrated by the surface flux of oxygen into the sediment, the depth-integrated reaction rates (DIRs) of oxygen with organic matter $\left(C_{\text {org }}\right)$ and with the reactive Fe(II) layer, and the oxygen penetration depth (OPD) over time. The influence of the bioturbation recovery time is shown by plotting the lines that correspond to a recovery interval of 100 and 200 years in black and grey, respectively.

Recovery of the sediment that was affected by the oxygen flooding scenario occurs within 100 years and is already in a near-pre-impact state 1 year after the disturbance. Here, the Fe(II)-oxygen reaction layer is predominantly responsible for restricting the anomalously high oxygen levels within the upper $20 \mathrm{~cm}$ of the sediment. Organic-matter degradation rates remain high throughout the recovery process, and build-up of fresh labile organic matter that replenishes the loss through the introduction of anomalous oxygen concentration occurs within the recovery phase of the bioturbation (Fig. 11). 

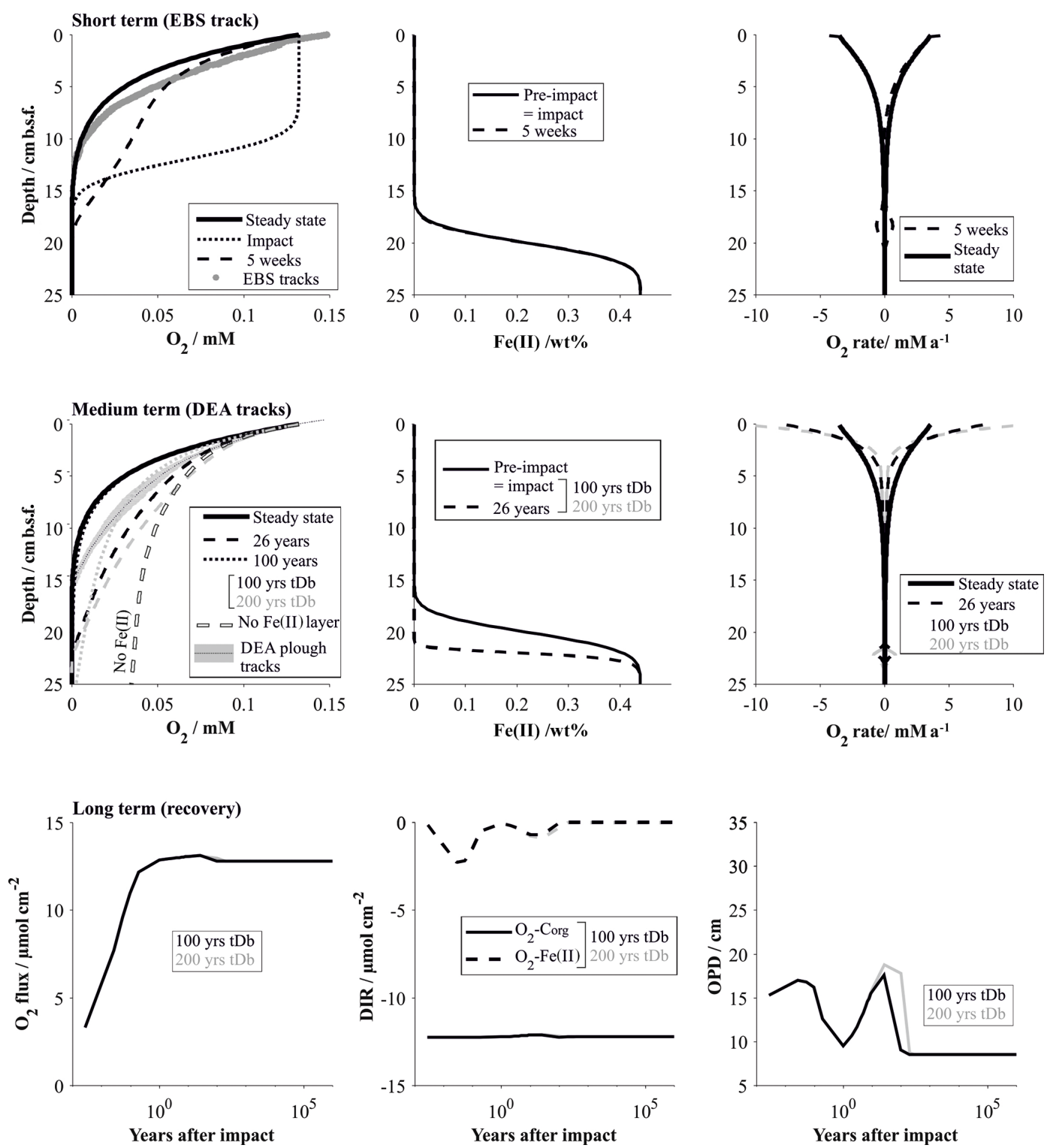

Figure 11. Impact simulations after a disturbance causing the upper sediment layer to be exposed to bottom water oxygen levels (i.e. through mixing or by resettling sediments; see Fig. 9). See the caption of Fig. 10 for details.

\section{Discussion}

The benthic ecosystem is shaped by a balanced interplay of physical, chemical and biological factors, which are fuelled by the deposition of organic matter, especially its labile fraction (Fig. 12): the degradation of organic matter is microbially catalysed and in turn provides nutrients to the microbial community (e.g. Witte et al., 2003a; Moodley et al., 2005; Stratmann et al., 2018b; Sweetman et al., 2018). The associated microbial growth provides biomass that sustains micro- and macrofauna and forms an important component of the benthic food web (Witte et al., 2003b; Van Oevelen et al., 2006, 2011). The concomitant bioturbation of the sediment induces a variety of changes, such as lower- ing the sediment shear strength and the vertical transport of fresh reactive organic matter into deeper sediments (bioturbation) through burrowing invertebrates (Krantzberg, 1985, and references therein). The occurrence of labile organic matter in deeper sediments where oxygen is not as easily replenished compared to surface sediments places an important restriction on the oxygen penetration depth (Haeckel et al., 2001). Bioturbation plays thus a deciding factor in early diagenetic, especially redox-sensitive, processes. These are typically closely linked to the microbial functions and, with the introduction of fresh and digested organic matter at depth by infauna, new material for additional degradation and microbial colonization, close the causal cycle (Levin et al., 1997; Witte et al., 2003a; Middelburg, 2018). Changes in any com- 
(a)
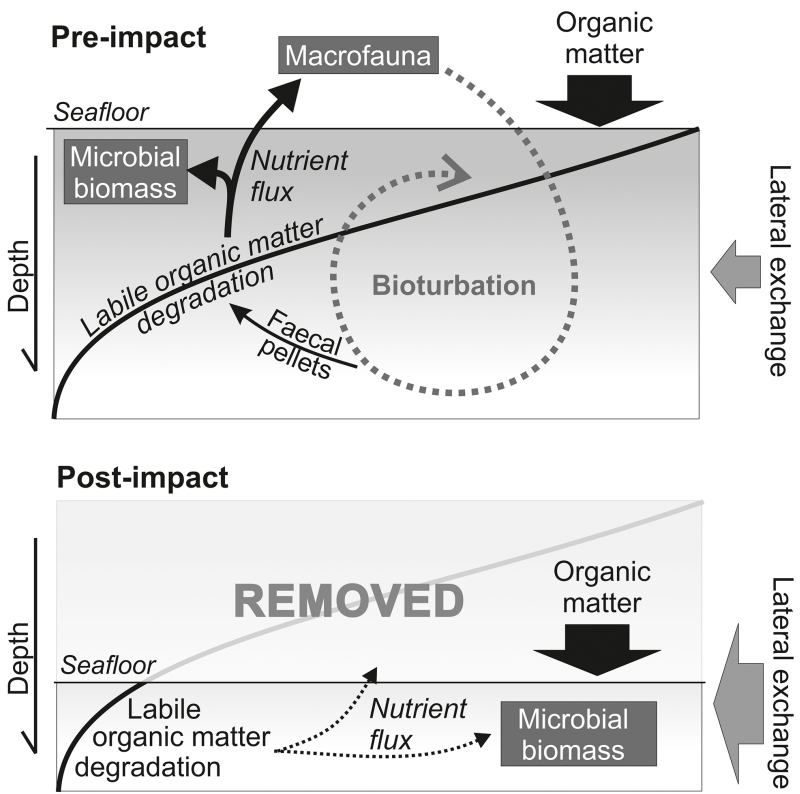

(b)
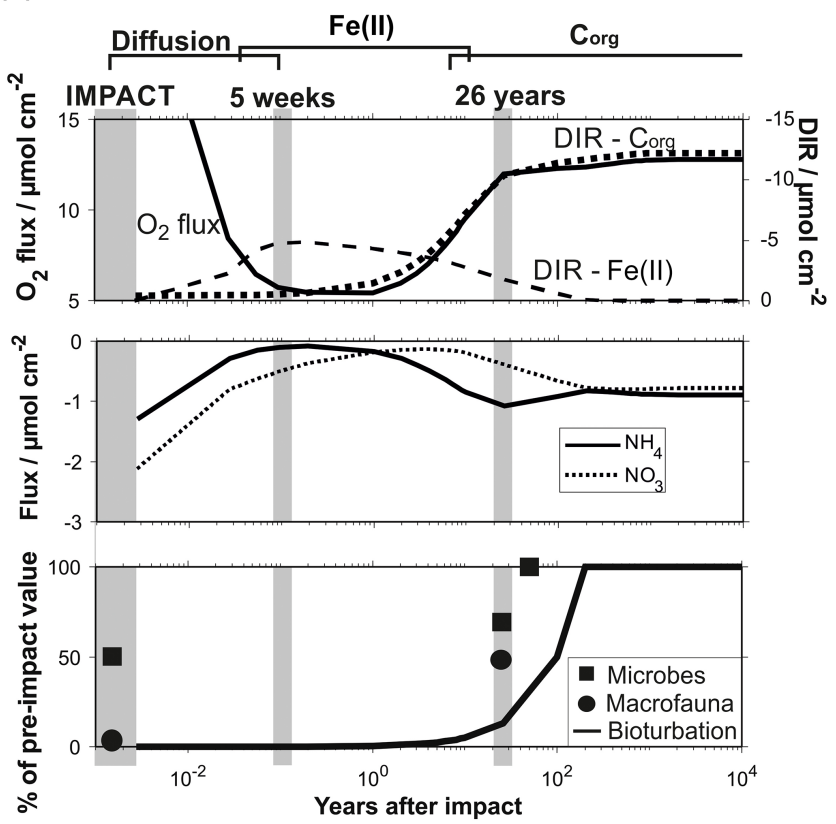

Figure 12. (a) Schematic diagram showing the delicate interplay between the distribution of organic matter, microbial activity and the bioturbation through burrowing megafauna in a pre-impact system and after removal of the upper reactive sediment layer. (b) Quantitative comparison of geochemical and biological processes over time after an impact through sediment removal. Biological data are taken from Stratmann et al. (2018a; macrofaunal abundance) and Vonnahme et al. (2020; microbial cell count) for the most severely disturbed sites (e.g. inside 5-week-old EBS tracks and inside 26-year-old plough marks). partment of the ecosystem functions will entail modifications of all biogeochemical processes. A natural example is the long-term glacial and interglacial or short-term ENSOdriven change in the depositional flux of organic matter to the seafloor, imposing gradual cycles in the redox zonation of the sediment (König et al., 2001).

Mining the seafloor will have an abrupt and direct impact on several benthic ecosystem functions at a time: (i) through the removal of all seafloor fauna (Vanreusel et al., 2016; Jones et al., 2017; Gollner et al., 2017; Bluhm, 2001; Borowski, 2001), (ii) through changing the physical characteristics of the sediment surface, i.e. by exposing more compacted sediments with increased shear strength, and removing manganese nodules as hard-substrate habitats (Grupe et al., 2001), and (iii) through the displacement and removal of labile organic matter.

Biological, geochemical and numerical results of the MiningImpact project significantly improve our understanding of the interlinked ecosystem recovery processes in the deep sea. Removal of the upper reactive surface layer and its fauna will halt bioturbation and organic degradation rates and significantly decrease microbial activity (Fig. 12a and b). Based only on deep-sea typical microbial biomass turnover rates and conservative bacterial doubling times, recovery of microbial abundances should occur within 210 years. Observations show, however, that the microbial activity remained significantly reduced in the decades following the DISCOL disturbance experiment (Vonnahme et al., 2020). Microbial recovery thus appears controlled by the re-establishment of the labile organic-matter fraction, which is still significantly reduced at this timescale. Low nutrient fluxes and the downsized microbial biomass cannot sustain pre-impact faunal abundances (Stratmann et al., 2018a), and recolonization is obstructed by the comparatively hard substrate and absence of hard-substrate habitats (nodule surface) in impacted areas (Vonnahme et al., 2020). This directly affects the macrofaunal efficiency to mix surface sediments into deeper layers, which is presented in the simulations by the reduced bioturbation coefficient (Fig. 12). It should be noted that even if sediment physical conditions and organicmatter availability have recovered, it is unclear whether the pre-impact infauna is still available to recolonize the disturbed area.

Prognostic simulations showed that the timescale of the ecosystem recovery ultimately depends only on one factor: the availability of labile organic matter. The amount of reactive organic matter determines the intensity of the food-web activity (i.e. summed carbon cycling; Stratmann et al. 2018a) and has to reach pre-impact levels to allow for the interlinked ecosystem to recover. In this context, two aspects should be particularly emphasized. (i) Deep-sea sediments are characterized by extremely low surface sedimentation rates $(\sim$ $0.004 \mathrm{~cm} \mathrm{a}^{-1}$ ) and thus organic-matter influx, so complete recovery of the labile organic-matter fraction takes up to 1000 years (Fig. 12). In the Clarion-Clipperton Zone, located 
also in the abyssal plains of the Pacific Ocean, surface sedimentation rates are even lower $\left(0.0002-0.001 \mathrm{~cm} \mathrm{a}^{-1}\right.$; Volz et al., 2018). In this area, where nodule mining is expected to commence, potential impact recovery after removal of the upper reactive layer was predicted to occur at an even longer (millennia) timescale (Volz et al., 2020). (ii) Ecosystem impact and consequent recovery are strongly dependent on the type of disturbance, more precisely, on the amount of labile organic matter removed. Microbial activity at disturbed sites could be directly correlated to an arbitrary disturbance gradient (Vonnahme et al., 2020), which in turn coincides with the thickness of the reactive dark brown surface sediments that were removed during the experimental disturbance. These findings are in line with the results of the prognostic simulations, which showed that the impact is much less severe and that recovery times significantly reduced (decades; Fig. 11) if sediments are simply mixed or affected by resettling sediment (oxygen flooding scenario) compared to the removal of the upper reactive layer (centuries; Figs. 10 and 12).

\section{Conclusions}

Previous diagenetic models of the DEA (Haeckel et al., 2001) were updated by a field-based bioturbation coefficient and application of a $3 \mathrm{G}$ organic-matter model. A near-surface $\mathrm{Fe}(\mathrm{II})$-oxygen reaction layer was introduced in the prognostic simulations, which represents the refractory Fe(II) phase that did not react with the downward-progressing interglacial nitrate front. The surprisingly similar oxygen penetration depths in reference and 26-year-old disturbed sediments indicate that this refractory $\mathrm{Fe}(\mathrm{II})$ appears to be an efficient barrier for the progressing oxygen front, thus defying previous impact simulation that predicted a significant downward migration of the oxygen front (König et al., 2001).

Transient simulation results have significantly enhanced the quality of the interpretation of the observed geochemical profiles, which at first sight do not exhibit marked differences among the various disturbed and reference sites. The geochemical recovery after a mining-related removal of the upper reactive sediment layer can be divided into three stages: (i) the initial diffusion-driven equilibration of the post-impact profiles (within weeks of the impact), (ii) burning down of the $\mathrm{Fe}(\mathrm{II})$-oxygen reaction layer (decades after the impact) and (iii) re-establishment of the reactive organic-matter layer (centuries after the impact). If the reactive surface sediment is not removed but instead mixed or temporarily resuspended, anomalously high oxygen concentrations alter biogeochemical processes on a decadal scale, albeit much less severely.

The interdisciplinary (geochemical, numerical and biological) approach to characterize the impact of benthic disturbances on early diagenetic processes provided valuable information on post-impact processes. On the one hand it identifies variables that are suitable as indicators of benthic ecosystem health and also allow identification of significant adverse change of the benthic environment. Metabolites of microbial activity were found to be particularly sensitive to disturbances and can even resolve grades of impact (Vonnahme et al., 2020). Biogeochemical processes responded more subtly to the disturbance, with oxygen, nitrite and bioturbation activity being the most suitable variables. On the other hand, this work highlights the closely linked nature of different benthic ecosystem functions, which is also true during the recovery from mining impacts. The main factor constraining the time frame of the geochemical recovery is the availability of reactive (labile) organic matter, emphasizing the importance of the impact type (sediment removal versus mixing and resuspension) and also the natural depositional flux of organic matter onto the sediment surface (e.g. DEA versus the Clarion-Clipperton Zone). The microbial degradation of the available reactive organic-matter fraction defines the base of the food web structure, which eventually sustains metazoans. Some of the epifauna burrows into the seafloor (bioturbation) and in turn has a critical influence on geochemical, especially redox-sensitive, processes and fluxes. Recovery of the system is thus only possible if the ecosystem functions of all compartments are restored. Our results also show that it is important to identify regional features, such as the reactive $\mathrm{Fe}$ (II) layer in DISCOL sediments, because they may affect the biogeochemical response to a benthic disturbance drastically.

While biogeochemical fluxes may recover close to the pre-impact state, the nodule ecosystem cannot recover, since the essential hard substrate, the polymetallic nodules, have been removed. Consequently, a new nodule-free ecosystem with very different faunal communities, functions and services has to be established in the mining areas and its thickly blanketed surrounding. Furthermore, this new ecosystem will take much longer timescales to establish because it is largely controlled by the recovery of the underlying biogeochemical fluxes and processes that fuel abyssal life.

Data availability. The geochemical data presented in Figs. 3, 4 and 6 are publicly available in the PANGAEA database with the DOI https://doi.org/10.1594/PANGAEA.905377 (Haeckel, 2019). The PANGAEA database also hosts the activity measurements of the ${ }^{210} \mathrm{~Pb}$ series presented Fig. 7, with the DOIs https://doi.org/10.1594/PANGAEA.905442 (de Stigter, 2019a, alpha spectrometry) and https://doi.org/10.1594/PANGAEA.905443 (de Stigter, 2019b, gamma spectrometry).

Author contributions. LH prepared the paper with substantial contributions from all co-authors. MH devised this study and conducted the onboard coring, sampling and chemical analyses of presented solid phase and pore water data. FJ carried out the in situ oxygen measurements during expedition SO242/2 and contributed the data for model validations. HdS provided the ${ }^{210} \mathrm{~Pb}$ radioactive data series which allowed for the quantification of the bioturbation intensity. LH and MH conducted the biogeochemical model simulations. 
Competing interests. The authors declare that they have no conflict of interest.

Disclaimer. The authors are solely responsible for the content of this paper.

Special issue statement. This article is part of the special issue "Assessing environmental impacts of deep-sea mining - revisiting decade-old benthic disturbances in Pacific nodule areas". It is not associated with a conference.

Acknowledgements. The authors would like to thank Anke Bleyer, Regina Surberg, Bettina Domeyer and Kristin Hamann for coworking on sample collection on the RV Sonne and onboard and onshore pore water analyses. Axel Nordhausen, Tobias Vonnahme, Frank Wenzhöfer and Cäcilia Wigand are acknowledged for their contribution to in situ measurements during the RV Sonne expedition. Piet van Gaever is thanked for carrying out the radionuclide analysis. We are also indebted to the captain and crew of the RV Sonne for their invaluable support during the cruise SO242. We are grateful for the constructive comments of two anonymous reviewers.

Financial support. This work was funded by the German Federal Ministry of Education and Research through the MiningImpact project (grant nos. 03F0707A, 03F0707D, 03F0812A and 03F0812D) of the Joint Programming Initiative of Healthy and Productive Seas and Oceans (JPIO). In that same project context, Henko de Stigter received funding from the Dutch Research Council (NWO) (grant no. 856.14.003).

The article processing charges for this open-access publication were covered by a Research Centre of the Helmholtz Association.

Review statement. This paper was edited by Jack Middelburg and reviewed by two anonymous referees.

\section{References}

Berner, R. A.: Early Diagenesis - A Theoretical Approach, Princeton University Press, Princeton, New Jersey, 241 pp., 1980.

Bluhm, H.: Re-establishment of an abyssal megabenthic community after experimental physical disturbance of the seafloor, DeepSea Res. Pt. II, 48, 3841-3868, https://doi.org/10.1016/S09670645(01)00070-4, 2001.

Boetius, A.: RV SONNE Cruise Report SO242-2: JPI OCEANS Ecological Aspects of Deep-Sea Mining, DISCOL Revisited, 2015.

Borowski, C. and Thiel, H.: Deep-sea macrofaunal impacts of a large-scale physical disturbance experiment in the Southeast Pacific, Deep-Sea Res. Pt. II, 45, 55-81, https://doi.org/10.1016/S0967-0645(97)00073-8, 1998.

Borowski, C.: Physically disturbed deep-sea macrofauna in the Peru Basin, southeast Pacific, revisited 7 years after the experimental impact, Deep-Sea Res. Pt. II, 48, 3809-3839, 2001.

Boudreau, B. P.: Diagenetic Models and Their Implementation: Modelling Transport and Reactions in Aquatic Sediments, Springer-Verlag, Berlin, Heidelberg, New York, 414 pp., 1996.

Breland, J. and Byrne, R.: Spectrophotometric procedures for determination of sea water alkalinity using bromcresol green, DeepSea Res. Pt. I, 40, 629-641, 1993.

Brenke, N.: An Epibenthic sledge for operations on marine soft bottom and bedrock, Mar. Technol. Soc. J., 39, 10-21, https://doi.org/10.4031/002533205787444015, 2005.

de Stigter, H.: Radionuclide data (total ${ }^{210} \mathrm{~Pb}$ ) measured on sediment multi cores during SONNE cruise $\mathrm{SO} 242 / 1$ at the DISCOL area, Peru Basin, PANGAEA, https://doi.org/10.1594/PANGAEA.905442, 2019a.

de Stigter, H.: Radionuclide ${ }^{210} \mathrm{~Pb}$ and ${ }^{226} \mathrm{Ra}$ data measured on sediment cores during SONNE cruise SO242/1, PANGAEA, https://doi.org/10.1594/PANGAEA.905443, 2019b.

Drodt, M., Trautwein, A. X., König, I., Suess, E., and Koch, C. B.: Mössbauer spectroscopic studies on the iron forms of deep-sea sediments, Phys. Chem. Miner., 24, 281-293, https://doi.org/10.1007/s002690050040, 1997.

Froelich, P. N., Klinkhammer, G. P., Bender, M. L., Luedtke, N. A., Heath, G. R., Cullen, D., Dauphin, P., Hammond, D., Hartman, B., and Maynard, V.: Early oxidation of organic matter in pelagic sediments of the eastern equatorial Atlantic: suboxic diagenesis, Geochim. Cosmochim. Ac., 43, 1075-1090, 1979.

Gollner, S., Kaiser, S., Menzel, L., Jones, D. O. B., Brown, A., Mestre, N. C., van Oevelen, D., Menot, L., Colaco, A., Canals, M., Cuvelier, D., Durden, J. M., Gebruk, A., Egho, G. A., Haeckel, M., Marcon, Y., Mevenkamp, L., Morato, T., Pham, C. K., Purser, A., Sanchez-Vidal, A., Vanreusel, A., Vink, A., and Martinez Arbizu, P.: Resilience of benthic deep-sea fauna to mining activities, Mar. Environ. Res., 129, 76-101, https://doi.org/10.1016/j.marenvres.2017.04.010, 2017.

Goloway, F. and Bender, M.: Diagenetic models of interstitial nitrate profiles in deep sea suboxic sediments, Limnol. Oceanogr. 27, 624-638, 1982.

Grasshoff, K., Ehrhardt, M., and Kremling, K.: Methods of Seawater Analysis, 3 Edn., Wiley-VCH, Weinheim, 600 pp., 1999.

Greinert, J.: RV SONNE Cruise Report SO242-1 JPI OCEANS Ecological Aspects of Deep-Sea Mining DISCOL Revisited, GEOMAR, 290 pp., 2015.

Grupe, B., Becker, H. J., and Oebius, H. U.: Geotechnical and sedimentological investigations of deep-sea sediments from a manganese nodule field of the Peru Basin, Deep-Sea Res. Pt. II, 48, 3593-3608, https://doi.org/10.1016/s0967-0645(01)000583,2001

Haeckel, M.: Geochemistry of sediment cores during SONNE cruises SO242/1 and SO242/2 at the DISCOL area, Peru Basin, PANGAEA, https://doi.org/10.1594/PANGAEA.905377, 2019.

Haeckel, M., König, I., Riech, V., Weber, M., and Suess, E.: Pore water profiles and numerical modelling of Peru Basin deep-sea sediments, Deep-Sea Res. Pt. II, 48, 3713-3736, 2001. 
Hessler, R. R. and Jumars, P. A.: Abyssal community analysis from replicate box cores in the central North Pacific, Deep-Sea Res. Pt. I, 21, 185-209, 1974.

Jahnke, R. A., Emerson, S. R., Reimers, C. E., Schuffert, J., Ruttenberg, K., and Archer, D.: Benthic recycling of biogenic debris in the eastern tropical Atlantic Ocean, Geochim. Cosmochim. Ac., 53, 2947-2960, 1989.

Jones, D. O., Kaiser, S., Sweetman, A. K., Smith, C. R., Menot, L., Vink, A., Trueblood, D., Greinert, J., Billett, D. S., Arbizu, P. M., Radziejewska, T., Singh, R., Ingole, B., Stratmann, T., Simon-Lledo, E., Durden, J. M., and Clark, M. R.: Biological responses to disturbance from simulated deepsea polymetallic nodule mining, PLoS One, 12, e0171750, https://doi.org/10.1371/journal.pone.0171750, 2017.

Jorgensen, B. B.: A comparison of methods for the quantification of bacterial sulfate reduction in coastal marine sediments, II. Calculation from mathematical models, Geomicrobiol. J., 1, 29-47, https://doi.org/10.1080/01490457809377722, 1978.

König, I., Drodt, M., Suess, E., and Trautwein, A. X.: Iron reduction through the tan-green color transition in deep-sea sediments, Geochim. Cosmochim. Ac., 61, 1679-1683, 1997.

König, I., Haeckel, M., Drodt, M., Suess, E., and Trautwein, A. X.: Reactive Fe(II) layers in deep-sea sediments, Geochim. Cosmochim. Ac., 63, 1517-1526, 1999.

König, I., Haeckel, M., Lougear, A., Suess, E., and Trautwein, A. X.: A geochemical model of the Peru Basin deep-sea floor and the response of the system to technical impacts, Deep-Sea Res. Pt. II, 48, 3737-3756, 2001.

Krantzberg, G.: The Influence of Bioturbation on Physical, Chemical and Biological Parameters in Aquatic Environments, Environ. Pollut. A, 39, 99-122, 1985.

Levin, L., Blair, N., DeMaster, D., Plaia, G., Fornes, W., Martin, C., and Thomas, C.: Rapid subduction of organic matter by maldanid polychaetes on the North Carolina slope, J. Mar. Res., 55, 595611, 1997.

Luff, R. and Wallmann, K.: Fluid flow, methane fluxes, carbonate precipitation and biogeochemical turnover in gas hydrate-bearing sediments at Hydrate Ridge, Cascadia Margin: Numerical modeling and mass balances, Geochim. Cosmochim. Ac., 67, 34033421, 2003.

Lyle, M.: The brown-green color transition in marine sediments: A marker of the Fe(III)-Fe(II) redox boundary, Limnol. Oceanogr., 28, 1026-1033, 1983.

Martin, W. R., Bender, M., Leinen, M., and Orchardo, J.: Benthic organic carbon degradation and biogenic silica dissolution in the central equatorial Pacific, Deep-Sea Res., 38, 1481-1516, 1991.

Middelburg, J. J.: A simple rate model for organic-matter decomposition in marine-sediments, Geochim. Cosmochim. Ac., 53, 1577-1581, 1989.

Middelburg, J. J.: Reviews and syntheses: to the bottom of carbon processing at the seafloor, Biogeosciences, 15, 413-427, https://doi.org/10.5194/bg-15-413-2018, 2018.

Moodley, L., Middelburg, J. J., Soetaert, K., Boschker, H. T. S., Herman, P. M. J., and Heip, C. H. R.: Similar rapid response to phytodetritus deposition in shallow and deep-sea sediments, J. Mar. Res., 63, 457-469, 2005.

Murray, J. W., Grundmanis, V., and Smethie, W. M.: Interstitial water chemistry in the sediments of Saanich Inlet, Geochim. Cosmochim. Ac., 42, 1011-1026, 1978.
Paul, S. A. L., Gaye, B., Haeckel, M., Kasten, S., and Koschinsky, A.: Biogeochemical Regeneration of a Nodule Mining Disturbance Site: Trace Metals, DOC and Amino Acids in DeepSea Sediments and Pore Waters, Front. Mar. Sci., 5, 117, https://doi.org/10.3389/fmars.2018.00117, 2018.

Paul, S. A. L., Haeckel, M., Bau, M., Bajracharya, R., and Koschinsky, A.: Small-scale heterogeneity of trace metals including rare earth elements and yttrium in deep-sea sediments and porewaters of the Peru Basin, southeastern equatorial Pacific, Biogeosciences, 16, 4829-4849, https://doi.org/10.5194/bg-16-48292019, 2019.

Rabouille, C. and Gaillard, J.-F.: Towards the EDGE: Early diagenetic global explanation. A model depicting the early diagenesis of organic matter, $\mathrm{O}_{2}, \mathrm{NO}_{3}, \mathrm{Mn}$, and $\mathrm{PO}_{4}$, Geochim. Cosmochim. Ac., 55, 2511-2525, 1991a.

Rabouille, C. and Gaillard, J.-F.: A coupled model representing the deep-sea organic carbon mineralization and oxygen consumption of surficial sediments, J. Geophys. Res., 96, 2761-2776, $1991 \mathrm{~b}$.

Schriever, G. and Thiel, H.: Cruise Report DISCOL 3, Sonne cruise 7, Universität Hamburg, 59 pp., 1992.

Stratmann, T., Lins, L., Purser, A., Marcon, Y., Rodrigues, C. F., Ravara, A., Cunha, M. R., Simon-Lledó, E., Jones, D. O. B., Sweetman, A. K., Köser, K., and van Oevelen, D.: Abyssal plain faunal carbon flows remain depressed 26 years after a simulated deep-sea mining disturbance, Biogeosciences, 15, 4131-4145, https://doi.org/10.5194/bg-15-4131-2018, 2018a.

Stratmann, T., Mevenkamp, L., Sweetman, A. K., Vanreusel, A., and van Oevelen, D.: Has Phytodetritus Processing by an Abyssal Soft-Sediment Community Recovered 26 Years after an Experimental Disturbance?, Front. Mar. Sci., 5, 59, https://doi.org/10.3389/fmars.2018.00059, 2018b.

Sweetman, A. K., Smith, C. R., Shulse, C. N., Maillot, B., Lindh, M., Church, M. J., Meyer, K. S., Oevelen, D., Stratmann, T., and Gooday, A. J.: Key role of bacteria in the short-term cycling of carbon at the abyssal seafloor in a low particulate organic carbon flux region of the eastern Pacific Ocean, Limnol. Oceanogr., 64, 694-713, https://doi.org/10.1002/lno.11069, 2018.

Thiel, H. and Schriever, G.: Deep-sea mining, environmental impact and the DISCOL project, Ambio, 19, 245-250, 1990.

Van Oevelen, D., Moodley, L., Soetaert, K., and Middelburg, J. J.: The trophic significance of bacterial carbon in a marine intertidal sediment: Results of an in situ stable isotope labeling study, Limnol. Oceanogr., 51, 2349-2359, 2006.

Van Oevelen, D., Bergmann, M., Soetaert, K., Bauerfeind, E., Hasemann, C., Klages, M., Schewe, I., Soltwedel, T., and Budaeva, N. E.: Carbon flows in the benthic food web at the deep-sea observatory HAUSGARTEN (Fram Strait), Deep-Sea Res. Pt. I, 58, 1069-1083, 2011.

Vanreusel, A., Hilario, A., Ribeiro, P. A., Menot, L., and Arbizu, P. M.: Threatened by mining, polymetallic nodules are required to preserve abyssal epifauna, Sci. Rep., 6, 26808, https://doi.org/10.1038/srep26808, 2016.

Volz, J. B., Mogollon, J. L., Geibert, W., Arbizu, P. M., Koschinsky, A., and Kasten, S.: Natural spatial variability of depositional conditions, biogeochemical processes and element fluxes in sediments of the eastern Clarion-Clipperton Zone, Pacific Ocean, Deep-Sea Res. Pt. I, 140, 159-172, 2018.

Volz, J. B., Haffert, L., Haeckel, M., Koschinsky, A., and Kasten, S.: Impact of small-scale disturbances on geochemical condi- 
tions, biogeochemical processes and element fluxes in surface sediments of the eastern Clarion-Clipperton Zone, Pacific Ocean, Biogeosciences, 17, 1113-1131, https://doi.org/10.5194/bg-171113-2020, 2020.

Vonnahme, T. R., Molari, M., Janssen, F., Wenzhöfer, F., Haeckel, M., Titschack, J., and Boetius, A.: Effects of a deep-sea mining experiment on seafloor microbial communities and functions after 26 years, Sci. Adv., 6, eaaz5922, https://doi.org/10.1126/sciadv.aaz5922, 2020.

Weber, M. E., von Stackelberg, U., Marchig, V., Wiedicke, M., and Grupe, B.: Variability of surface sediments in the Peru basin: dependence on water depth, productivity, bottom water flow, and seafloor topography, Mar. Geol., 163, 169-184, https://doi.org/10.1016/s0025-3227(99)00103-6, 2000.

Welicky, K., Suess, E., Ungerer, C. A., Müller, P. J., and Fischer, K.: Problems with accurate carbon measurements in marine sediments and particulate matter in seawater: A new approach, Limnol. Oceanogr., 28, 1252-1259, 1983.
Westrich, J. T. and Berner, R. A.: The role of sedimentary organic matter in bacterial sulfate reduction: The $\mathrm{G}$ model tested, Limnol. Oceanogr., 29, 236-249, 1984.

Wilson, T. R. S., Thomson, J., Colley, S., Hydes, D. J., Higgs, N. C., and Sørensen, J.: Early organic diagenesis: The significance of progressive subsurface oxidation fronts in pelagic sediments, Geochim. Cosmochim. Ac., 49, 811-822, 1985.

Witte, U., Aberle, N., Sand, M., and Wenzhöfer, F.: Rapid response of a deep-sea benthic community to POM enrichment: an in situ experimental study, Mar. Ecol. Prog. Ser., 251, 27-36, 2003a.

Witte, U., Wenzhöfer, F., Sommer, S., Boetius, A., Heinz, P., Aberle, N., Sand, M., Cremer, A., Abraham, W.-R., Jørgensen, B. B., and Pfannkuche, O.: In situ experimental evidence of the fate of a phytodetritus pulse at the abyssal sea floor, Nature, 424, 763766, 2003b. 